\title{
Assessment of Nutrition of Obese Primary Schools Children in Urban and Rural Area in El Bihera Governorate- Egypt.
}

\author{
Hanaa H. Elsayed, Sahar Khairy, Mohamed K Abd El- Rahman and Effat A. Afifi \\ National Nutrition Nnstitute
}

\begin{abstract}
Background: The prevalence of obesity is increasing in both developed and developing countries. Obesity is associated with increased risks of many diseases. Obesity significantly affects the quality of life and reduces the average life expectancy.

Objective: Investigate effect of different environment urban and rural areas in El Bihera governorate on blood glucose level and obesity of children aged 6-12 years to know possible associated risk factors.
\end{abstract}

Study design: This study of a representative sample of children 6-12 y of age performed during 1 July 2004 till 20 June 2005.

Methods: Anthropometric data were taken using standard methods, from 188 children. Certain diet and physical activities as well as other socioeconomic family parameters were assessed with the aid of a questionnaire. Obesity and overweight were defined using both the National Health and Nutrition Examination Survey (NHANES)I definition and the new International Obesity Task Force (IOTF) definition. Logistic regression analyses were performed to estimate the influence of various parameters.

Results: obesity was prevalent among girls13.8 and $11.7 \%$ than boys 12.7 and $13.8 \%$ in urban and ruler areas respectively. The high percentage of boys and girls in both urban and rural (78.0\% and $84.2 \%$ respectively and $83.3 \%$ and $89.8 \%$ respectively), who take snacks in between meals. Also the results show that about three-quarter of the urban boys $(70.7 \%)$ and more than half of rural boys $(65.8 \%)$ eating during T.V watching. The results show that about two-third $(58.3 \%)$ of the urban girls and about three-quarter $(67.3 \%)$ of the rural girls eating during T.V watching with significant differences only among the urban groups (P 0.020). on the other hand, the plasma glucose values of all cases (normal and obese) in urban and rural areas were significantly different. In boys and girls subjects in rural and urban areas there were no significant differences between the mean values of plasma TSH. However, a significant difference between the plasma TC of urban areas than that of rural areas at the same age group was detected. There was a significant difference for the mean values of plasma TC level between normal and obese groups in the rural site.

Conclusion: The good news is that schools can help students and staff adopts healthy eating and physical activity behaviors that are the keys to preventing obesity.

Key words: Obesity - children - diabetes. 


\section{Introduction:}

Obesity is often defined simply as a condition of abnormal or excessive fat accumulation in adipose tissue, to the extent that health may be impaired. However, the distribution of fat within the body and the associated health consequences vary between obese individuals (WHO, 2000). Obesity is a major risk factor for chronic disease and plays a central role in insulin resistance and it is associated with decreased insulin sensitivity, and increased total cholesterol and triglycerides (Lurbe, et al., 2008).

The rapidly increasing prevalence of obesity among children and adolescents is one of the most challenging dilemmas facing pediatric care professionals today. Childhood and adolescent obesity are important risk factors for adult obesity, with its consequent morbidity and mortality (Whitaker, et al., 1997). Therefore, prevention and/or treatment of childhood and adolescent obesity offer the best hope of preventing adult obesity and its related morbidities.

The prevalence of obesity in children has increased significantly in developed countries but less rapidly, in developing ones (Chinn and Rona, 2001). This trend is of major concern given the consequences that associated with childhood obesity. The percentage of children who are obese has more than doubled (Ogden, et al., 2008), and among adolescents the rates have more than tripled since 1980 .

The "obesogenic" environment appears to be largely directed at the adolescent market, making healthy choices that much more difficult. At the same time, exercise patterns have changed and considerable parts of the day are spent sitting at school, in a work, or in front of a television or computer. Raised blood pressure, impaired glucose tolerance and dyslipidaemia are associated in adults children and adolescents with unhealthy lifestyles, such as diets containing excessive intakes of fats (especially saturated), cholesterol and salt, an inadequate intake of fiber and potassium, a lack of exercise, and increased television viewing Physical inactivity and smoking have been found independently top predict cardiovascular heart diseases (CHD) and stroke in later life. (Aboderin, 2002)

El Behaira governorate which was lies in the north of the Nile Delta and was the other representing governorate, 1477 school children in the age group 6-<12years in urban areas were examined. Prevalence of overweight and obesity among boys was $7.6 \%$ and $11.8 \%$ among in girls. It was much less in rural areas as among 3489 children only $3.8 \%$ and $3 \%$ boys and girls respectively were overweight and obese.

\section{Patients and Methods:}

From this sample examined those who accepted to be included in this study was 188 individuals, 101 of them were living in urban areas, 41 boys and 60 girls and 87 in rural areas, 38 boys and 49 girls. The sample included ninety apparently healthy children as a control, and ninety eight obese children in age groups from six years to twelve years. This study as a part from project was done by National Nutrition Institute called" obesity, its Relation to dietary pattern prevention and management."

\section{1- Anthropometric Measurements:}

Anthropometric Measurements namely weight and height percentage / age to indicator to nutritional status. The subject was weighed by standing bare footed on the center of the platform without touching or leaning on anything and with light clothing worn and determined and accordingly corrections were done (WHO, 1995). The subject was placed bare footed underneath the measuring arm, feet parallel and with heels, buttocks, shoulders and back of head touching the wall. The head was held comfortably erect and the outer border of the orbit with the external auditory meat us in the same horizontal plane (Frankfort Plane). The arms were hanging relaxed at the sides. The measuring arm was brought down on to the subject's head with the back plate firmly against the wall. The red cursor line was giving the accurate height measurement (WHO, 1995). Duplicate observers for both weight and height were used. 


\section{2- Social Status Assessment}

Assessment of social status of the family was done according to (Park and Park, 1979). The method is based on the education and occupation of both father \& mother. A score was given and the families were divided into three groups: low, middle or high social status.

\section{3- Dietary Assessment:}

Methods used for measuring food consumption of the surveyed families were classified into two major groups (Gibson, 1998). The first group, known as quantitative daily consumption method, consisted of recalls or records designed to measure the quantity of foods and beverages consumed over one day period "Twenty four-hour recall" method. The compiled food composition tables FCT of the Nutrition Institute were used to determine energy and nutrients intake of each individual. Adequacy of the diet consumed was assessed by comparing the energy and nutrient intake of the person with his recommended dietary allowances "RDA" (WHO, 1985; WHO, 1998; WHO, 2000). The second group of methods included the dietary pattern and food frequency questionnaire.

Dietary pattern "Food Frequency Questionnaire": This method was used to obtain qualitative descriptive information about usual food and beverage consumption pattern for the whole family per week (less than 3 times per week or equal or more than 3 times per week). This questionnaire includes:

- Energy foods: Cereals and its products oils, fats - sugar and sweets

- Tissue building foods: Meat, chicken, fish, eggs, legumes, milk and its products

- Protective foods: Vegetables rich in carotene (high, moderate and low), fruits rich in calcium (high, moderate and low).

- Beverages: Tea, coffee, carcadeh, fenugreek, cocoa and fruit juice.

\section{4- Biochemical Parameters Determination}

Blood Samples: A venous blood sample of 5 $\mathrm{ml}$ was collected in heparinized tubes from $50 \%$ of total selected subjects. The rest of the blood was centrifuged to obtain the plasma first part of plasma was immediately determined glucose. The other part of plasma was divided into aliquots in five Ependorf vials and stored at -20 'c for the analysis. On each vial the ID and the name of the subject was recorded.

With the collected plasma, the following parameters were determined.

A - Determination of blood sugar: Enzymatic Colorimetric method of (Trinder, 1969).

B- Hormones:

- Thyroid stimulating hormone (TSH) was determined using kits according to (Burger and Patel, 1977).

C-Minerals: Zinc. Plasma zinc and Chromium concentration was determined by atomic spectrophotometer (UNICAM 929 atomic absorption spectrometer) after protein precipitation with trichloroacetic acid $(50 \mathrm{~g} / \mathrm{l})$ using the method of (Thomerson \& Price, 1971).

D- Lipid profile

-Total cholesterol was determined by Stanbia cholesterol liquicolor kit, Quantitative Enzymatic-Colorimetric Determination according to (Stein, 1986).

- Triglycerides: Serum triglycerides were determined according to the colorimetric method of Fossati and Principe, (1982) using the Biocon enzymatic kit.

- Serum HDL-Cholesterol (HDL-C): It was determined according to the method of Gordon, et al. (1977) using Biocon enzymatic kit.

- Serum LDL-cholesterol (LDL-C): was calculated by equation according to the Friedwald, et al., (1972) equation:

Serum LDL-C concentration in $(\mathrm{mg} / \mathrm{dL})=$

Total cholesterol- (HDL-C Triglycerides

\section{5- Statistical analysis}

The age (1 y interval for NHANES I definition and 6 month interval for IOTF definition) and sex-related prevalence of overweight and obese children were calculated using the previously mentioned cut-off points (Guo, et al., 1996). Logistic regression analysis was used to estimate odds ratios (ORs) for obesity (as defined by the IOTF definition) in children. All ORs with a P-value less than 0.05 were 
considered as statistically significant by (spss, 1996).

\section{Results}

From this sample examined, children who accepted to be included in this study was 188 individuals, 101 of them were living in urban areas and 87 in rural areas. The sample included from six years of age till twelve years. The number of primary school age children was $188,47.9 \%$ of them were normal and $52.1 \%$ were obese. Regarding sex, obesity was prevalent among girls 13.8 and $11.7 \%$ than boys 12.7 and $13.8 \%$ in urban and ruler areas respectively (table 1).

\section{Social factors:}

Socioeconomic status is usually presented as a composite index combining income education occupation and in some developing countries place of residence (urban or rural). Studies have reported that socioeconomic status is negatively correlated with obesity in developed countries but is positively related to obesity in developing countries (Barlow and Dietz, 1998)

\section{Family size:}

All the individuals were divided into three groups according to the size of the family
1) Less than 5 members
2) 5-9 members
3) more than 9 members

Among males most of them belonged to family size 5-9 in both urban and rural areas. The big family size was found only in rural areas. The same was observed among girls as shown in table (2).

\section{Educational level:}

Educational levels of the sample were divided into several groups:

1-Illiterate 2- read and write without school attendance 3-school attendance (primary, preparatory)

\section{Family level table (2)}

It was divided into three levels according to Park and Park, 1977:
1- High
2- intermediate
3- low

Very few cases belonged to the high family social level in both sites and gender. Among boys in the age group most of them belonged to the intermediate score in urban and to the low score in rural areas.
Regarding the relation between family size and obesity it was obvious that obese belonged to large families (5-9 persons) in both sites among boys and urban girls, while there was no difference among rural girls.

There was no relation between the level of education and obesity, while the role of family score played a more important role as obese belonged to middle and low social level rather than high family score.

Table (3) Assessment of Weight and Height Status: Weight status for children was assessed using NCHS reference standard and weight for height Z- scores. The following categories of weight status were determined: Wasting <-2 SD. - Normal -2 to +2 SD. Overweight $>+2$ SD. For children weight and height were used to study weight status and classified to normal weight, and obese, according to WHO, (1995) based on weight and height (z-score). Table (3) showed that the mean weight measurements were significantly higher among obese individuals than those of normal weight with obese groups. There was no difference regarding the mean $\mathrm{z}$-score among girls and also between urban and rural areas. Central obesity was observed to be more among boys than girls with no significant difference in both sites.

Tables (4) show the different opinions of the individuals regarding the main factors leading to obesity. In the age group, the diet was the main factor in both gender and sites. For individuals' opinion of food items related to obesity table (5) show that carbohydrate, sweets, fats food were the main items chosen by most obese in both sites.

\section{Food intake}

Dietary habits: While behavioral therapy has had some success in treating obesity in young children (aged 6-12 years), most studies have found that the long-term success of such therapy depends on the type of intervention used (Epstein, et al., 1990; Epstein, et al., 1994; Somerbell, et al., 2003 and Epstein, et al., 2001). It is possible that pharmacotherapy could play a significant role in improving the results obtained with behavioral therapy.

Tables (6 and 7) show distribution of the study groups (normal and obese) for primary school children $(6-<12$ years) according to dietary habits, dietary pattern and diversity, dietary adequacy and comparison with 
population nutrient goals. Lunch was main meal among most of the urban and rural boys $(87.8 \%$ and $87.5 \%$ respectively) without significant differences among groups in both urban and rural. Also the results show that about three-quarter of the urban boys $(70.7 \%)$ and more than half of rural boys (65.8\%) eating during T.V watching. There was no significant difference among the two study groups in both urban and rural. The results revealed that more than half of both urban and rural boys (65.9\% and $68.5 \%$ respectively), didn't consume fast foods without significant differences among study groups in both urban and rural. And girls, about two-third of the girls in both urban and rural $(60.0 \%$ and 73.5 $\%$ respectively), take three meals per day. While only $(26.7 \%)$ in urban and $(16.3 \%)$ in rural take two meals per day. Few of them $(10 \%)$ and (10.2) respectively, take more than three meals per day without significant differences among groups. Most of the girls in both urban and rural $(81.7 \%$ and $77.6 \%$ respectively), said that lunch is the main meal. While a few of the urban girls $(13.3 \%)$ said that the dinner is the main meal and a few of the rural girls (10.2\%) said that breakfast is the main meals. The results showed that there were no significant differences among the study groups in both urban and rural. The majority of both the urban and rural girls (83.3\% and $89.8 \%$ respectively), take snacks in between meals without significant differences among groups in both urban and rural. The results show that about two-third $(58.3 \%)$ of the urban girls and about threequarter $(67.3 \%)$ of the rural girls eating during T.V watching with significant differences only among the urban groups $(\mathrm{P} \leq 0.020)$. Fast foods were consumed by only about one- third of both urban and rural girls (38.3\% and $22.4 \%$ respectively), without significant differences among study groups in both urban and rural.

One-third of the urban girls (23.8\%) brought beverages and chips from school. There was a significant difference only among the urban study groups $(\mathrm{P} \leq 0.051)$.

Tables (8) and (9) show mean intake \pm S.D and adequacy diet of children with the study groups (normal and obese) regarding energy and macronutrients.
Energy: The mean RDA of energy was $(2250 \mathrm{kcal})$. The lowest mean intake of energy was found among those of normal boys group in urban $(2459.7 \mathrm{Kcal})$. There were significant differences among the normal and obese groups. In rural area the lowest mean intake \pm S.D was among normal group $(2531.4 \mathrm{Kcal})$. There were no significant differences among the two sites of obese groups. All boys got > $100 \%$ of their RDA from energy .These results revealed that the more high intake of energy, the more prevalence of obesity.

For girls the total mean intake of energy was (2699.0) Kcal in urban while, it was (2700.0) Kcal in rural; the highest mean intake was found among those of obese girls in both urban and rural areas (3092.0 and 3072.0 Kcal respectively). The majority of girls got $\geq 100 \%$ of their RDA. There were no significant differences among the study groups.

Protein: In urban, all groups got $>100 \%$ of their RDA from protein in two sites. There were no significant differences among the study groups in both urban and rural areas. Girls in urban the total mean intake was (99.6 $\mathrm{g}$ ), the highest mean intake (108.2 g) was found among those of obese and the lowest mean intake $(91.0 \mathrm{~g})$ was found among those of normal weight. .While, in rural the total mean intake was $(91.4 \mathrm{~g})$ the highest and the lowest mean intake were (97.1 and $85.6 \mathrm{~g}$ ) was found among those obese and normal girls respectively. Also the majority of girls were in both urban and rural got $>100 \%$ of their RDA from protein. There was no significant difference among two sites.

Fat: The lowest mean intake for boys in both urban and rural was observed among those of normal weight (90.1 $\mathrm{g}$ and $92.2 \mathrm{~g}$ respectively) without significant differences among the study groups. The total mean intake for girls was (98.6 and $82.4 \mathrm{~g}$ ) in urban and rural respectively. The lowest mean intake was found among those of normal girls weight in urban and rural (72.1 and $71.8 \mathrm{~g}$ ) respectively.

Carbohydrates: The results revealed that in urban those of obese weight consumed the highest mean intake of carbohydrates (438.6 g) also in rural the highest mean intake of carbohydrates (450.9 g) was observed among the obese boys. There was no significant difference among groups in two areas. The results represent that the total mean intake of 
carbohydrate was higher in rural than urban $(397.5$ and $353.1 \mathrm{~g})$ respectively. But the highest consumption was found among those of obese girls in both rural and urban (460.1 and $383.3 \mathrm{~g}$ ) respectively.

Cholesterol: In both urban and rural areas the lowest consumption of cholesterol was observed among those of normal weight without significant differences among the studied groups. However, among the obese boys in urban area cholesterol intake was higher than $(300 \mathrm{mg})$ which is the maximum level allowed as recommended by (WHO, 2003). The total mean intake of girls was higher in urban than rural (241.6 and 203.3 $\mathrm{mg}$ ) respectively. The highest consumption of cholesterol was observed among those of obese girls (313.7 and $229.0 \mathrm{mg}$ ) in urban and rural.

Tables (10 \& 11): show that mean intake \pm S.D and dietary adequacy of selected minerals (Calcium, Iron, Zinc, Copper and Selenium).

Calcium: There were significant differences in both urban and rural. The results show that the total mean intake in urban was (1247.8 $\mathrm{mg})$; the lowest mean intake (1149.3 $\mathrm{mg}$ ) was found among those of normal weight boys while, the highest mean intake (1346.3 $\mathrm{mg}$ ) was found among obese boys. As for rural area the total mean intake was $(853.7 \mathrm{mg}$ ) while, the lowest mean intake $(833.0 \mathrm{mg}$ ) was belonging to those of normal weight and the highest mean intake $(874.4 \mathrm{mg})$ belonging to those of obese boys. The results also show that the majority of boys in both urban got $>100 \%$ of their RDA from Calcium. There were significant differences between the studied groups in both urban and rural. In urban the results show that the total mean intake was $(1077.5 \mathrm{mg})$ while the highest mean intake (1111.4 mg) was belonged to those of normal weight and the low mean intake $(1043.5 \mathrm{mg}$ ) was belonged to those of obese girls; while the total mean intake of Calcium in rural was $(833.9 \mathrm{mg})$ and the highest mean intake $(884.3$ $\mathrm{mg}$ ) was also belonging to those of normal weight but the low mean intake $(783.5 \mathrm{mg}$ ) belonging to the obese group. The majority of the sample in urban area got $>100 \%$ of their RDA from Calcium.

Iron: Also there were no significant differences among the levels of weight status in both urban and rural regarding mean intake and adequacy of diet. The total mean intake of Iron in both urban and rural was (28.0 and 26.1 $\mathrm{mg}$ respectively); but the highest mean intake was belonging to the obese boys in urban. The high percent of boys in levels of weight status in both urban and rural got $>100 \%$ of their RDA. There was significant differences e in both urban and rural. Girls in urban; the results reflect the significant differences among those of normal weight in urban and ruler, regarding their mean intake of Iron (23.7, and $33.2 \mathrm{mg}$ respectively). The highest mean intake (33.2 $\mathrm{mg}$ ) was belonged to those of normal weight and the low mean intake (24.8 $\mathrm{mg})$ was belonged to the obese group. At the same time the results show that urban and ruler girls got $>100 \%$ of their RDA from Iron.

Zinc: There was no differences regarding mean intake and diet adequacy of Zinc among boys in both urban and rural as the total mean intake was $(11.1 \mathrm{mg}$ and $11.0 \mathrm{mg}$ respectively). Also the high percent of boys got $>100 \%$ of their RDA. Also the results show that there was no significant difference in both urban and rural. The highest mean intake of Zinc (9.8 and $10.6 \mathrm{mg}$ ) in urban and rural respectively was belonged to the obese girls. Total girls in urban got $78.0 \%$ of their RDA from Zinc while in ruler got $84.0 \%$ of their RDA without significant differences among study groups.

Copper: All boys in both urban and rural have got $<50 \%$ of their RDA. There was significant difference among obese status in both urban and rural regarding mean intake of Copper. The results reflect that the total mean intake of Copper was $(0.07 \mu \mathrm{g}$ and $0.12 \mu \mathrm{g})$ in both urban and rural respectively with significant differences among the study groups. All the urban and rural girls got $<50 \%$ of their RDA from Copper.

Selenium: There were no significant differences in both urban and rural. The total mean intake was similar in urban and rural (37.6 $\mathrm{mg}$ and $36.9 \mathrm{mg}$ respectively). All boys got $>100 \%$ of their RDA. The highest mean intake ( 33.7 and $35.9 \mathrm{mg}$ ) was belonged to those of normal weight in the two areas. Total of the urban girls got $92.6 \%$ from their RDA but in rural all girls got $>100 \%$ of their RDA.

In tables (12) and (13): Show mean intake \pm S.D and dietary adequacy of water 
soluble vitamins. Vitamins B1, B2, Niacin and Folic acid: The results revealed that there was significant difference among total status in both urban and rural regarding mean intake and dietary adequacy from vitamins B1, B2, Niacin and Folic acid. A high proportion of boys have got $>100 \%$ of their RDA from the previous vitamins in both urban and rural except folic acid got $86.1 \%$ in urban and $68.4 \%$ in ruler area of their RDA. The results revealed that there were significant differences among total intake of vitamin B1, B2, Niacin and Folic acid in both urban and rural. The highest mean intake of vitamin B1, B2, Niacin and Folic acid in rural was belonged to those of normal girls weight $(1.5, \quad 2.3, \quad 1.82$, and 79.8 respectively). Also the results show that the total urban girls got $>100 \%$ of their RDA from B1, B2 and niacin respectively while got $65.0 \%$ of their RDA from folic acid. In rural the girls got $>100 \%$ of their RDA from vitamins B1, B2, and Niacin respectively while they got $56.6 \%$ of their RDA from folic acid. All the B vitamins, as well as lecithin, are essential for healthy weight loss.

Vitamin C: Also there were no significant differences among boys in the three study groups in both urban and rural regarding mean intake and dietary adequacy from vit. $\mathrm{C}$. The total mean intake was(122.2 $\mathrm{mg}$ and $123.1 \mathrm{mg}$ ) in urban and rural respectively; the highest mean intake (135.2 $\mathrm{mg}$ ) was belonging to those of normal weight in urban while, in rural the highest mean intake (145.6 mg) was found among those of obese. All boys were in urban and rural got $>100 \%$ of their RDA from vit. C. The results revealed that there were significant differences in both urban and rural regarding mean intake and dietary adequacy from vit. $\mathrm{C}$. the lowest mean intake was belonged to those of normal weight in both urban and rural (106.7 and $114.6 \mathrm{mg}$ respectively) while the highest mean intake was belonged to the obese girls (128.2 and $173.2 \mathrm{mg}$ ) in both urban and rural respectively. All urban and rural girls got $>100 \%$ of their RDA.
Tables (14) and (15); show that mean intake \pm S.D and dietary adequacy of fat soluble vitamins.

Vitamin "A": The total mean intake from vitamin A in urban and rural was (986.8 and $705.0 \mu \mathrm{g}$ RE respectively); the highest mean intake $(981.2 \mu \mathrm{g} \mathrm{RE})$ belonged to obese boys in urban while, the highest mean intake in rural (773.9 $\mu \mathrm{g}$ RE) belonged to obese boys; with significant differences in both urban and rural.. In urban all boys got $>100 \%$ of their RDA without significant differences among the study groups, while, in rural total boys got $82.9 \%$ of their RDA and also there was significant differences among the study groups in rural. The results revealed that in urban the highest mean intake (1058 RE ) was belonged to those of normal girls weight while those of obese had the lowest mean intake (930.2 RE) . Urban girls got $>100 \%$ of their RDA. But in the rural those of normal weight got the lowest mean intake (668.3 RE) while the highest mean intake was belonged to the obese girls (763.9 RE). The total rural girls got $84.2 \%$ of their RDA. There were significant differences among the study groups in both urban and rural.

Vitamin" E": The total mean intake of both urban and rural boys was $(6.2$ and $7.1 \mathrm{mg}$ respectively); but the highest mean intake belonged to those of obese boys in rural (7.5 $\mathrm{mg}$ ). Total boys in urban and rural area got $72.9 \%$ of their RDA while, total boys in ruler got $83.5 \%$ of their RDA. Also the results show that there were no significant differences among the study groups in both urban and rural. While in urban girls mean intake was as a similar value. The total mean intake of urban girls was $(5.5 \mathrm{mg})$; while in rural the total mean intake was $(7.3 \mathrm{mg})$. Urban girls got 64.7 $\%$ of their RDA, while ruler girls got 85.9 of their RDA.

Table (16) show results of body composition fat analyzer according to sex, site and age group in El- Behaira governorate:

1-Basal Metabolic Rate (BMR) measured in

(Kcal) increased with increase in weight status (normal $=1262.8 \pm 114.17, \&$ obese $=1502.3 \pm$ 208.24 and $\mathrm{P}=0.000$ ).

BMR was higher in boys than girls (1509.6 \pm 191.68 vs. $1291.0 \pm 127.15, \mathrm{P}=0.000)$.

2-Fat Mass (FM) measured in (Kg) increased with increase in weight status 
(normal $=11.6 \pm 3.37$, obese $=20.7 \pm 7.45, \mathrm{P}=$ 0.000 ).

3-Fat Free Mass (FFM) measured in (Kg) was higher in boys than girls $(31.9 \pm 5.16$ vs. $30.4 \pm 5.05, \mathrm{P}=0.039$ ).

4-Total Body Water (TBW) measured in $(\mathbf{K g})$ was higher in boys than girls $(23.4 \pm 3.78$ vs. $22.3 \pm 3.70, \mathrm{P}=0.038$ ).

\section{Biochemical analysis}

Plasma Glucose: Data from table (17) showed that the plasma glucose level of both boys and girls subjects had significant difference $(p<005)$. On the other side, the plasma glucose value of all cases (normal and obese) in urban and rural areas was significantly different. There was no significant difference between the mean values of plasma glucose level in the normal and obese groups in urban site while in the rural site a significant difference was found between normal and obese group.

Lipids Profile: Results in table (17) showed that there was no significant difference between the mean values of plasma total cholesterol (TC), High density lipoproteinscholesterol (HDL-C), Low density lipoproteins- cholesterol (LDL-C) and triglycerides (TG) between boys and girls subjects. However, a significant difference between the plasma TC of urban areas than that of rural areas at the same age group was detected. There was a significant difference between the mean values of plasma TC level between normal and obese groups in the rural site.

Plasma TSH, body weight is presented in tables (17) which illustrated that boys and girls subjects in rural and urban areas there were no significant differences between the mean values of plasma TSH. The highest prevalence of hyperthyroidism was among the boys in the age group (6-12 years).

Plasma Chromium: Results in table (17) indicated that plasma level of Chromium of boys and girls subjects in the age groups (612 years) showed no significant difference, While, a significant difference were detected between urban and rural areas. On the other hand, the lowest prevalence of Chromium deficiency $(11.8 \%)$ was observed in girls in the age group (6-12 years).

Plasma Zinc: The results illustrated in tables (17) showed that there was no significant difference between sexes, sites and body weight status in the age groups. On the other hand, the lowest prevalence of zinc deficiency $(5.9 \%)$ was observed in girls in the age group (6-12 years).

\section{Discussion:}

There was a clear underestimation of obesity using IOTF data (or overestimation using NHANES I data) in younger children, both data sets, that is NHANES I data and IOTF cut-offs, were used in this study; the World Health Organization's (WHO) current recommendations suggest the use of NHANES I data (WHO, 1995). Tremblay and Willms, (2000) who estimated prevalence of obesity in their study as defined by the NHANES I data was close to the observed prevalence of obesity in the United States. In Canada, the overall prevalence of obese boys was (13.5\%) and girls (11.8\%) 7$13 \mathrm{y}$, that the results were accepted with the present results in this study. The overall Prevalence of obesity in children in the U.S. was 17\% in 2004 (Ogden, et al., 2006), these results were agreed with the data in table (1).

Regarding to table (2) the sociodemographic characteristics of the subjects are shown in it. Many studies have shown a positive association between parental and childhood obesity (Burke, et al., 2001). Various environmental factors have been implicated in the etiology of the increased prevalence of obesity, such as specific aspects of the home environment and family lifestyle, and sedentary activities and lack of physical activities (Trost, et al., 2001). The environments in which people live are complex and their individual and combined elements have a marked effect on people's behaviors and dietary intakes. Individuals interact in a variety of micro environments or settings such as schools, workplaces, homes, restaurants and fast food

outlets 140. These in turn are influenced by the broader macro-environments or sectors such as the food industry (Yanovsk and Sebring, 1994).

Data in tables from 8 to 15 showed that mean intake \pm S.D and adequacy diet of children with the study groups (normal and obese) 
regarding energy, macronutrients and micronutrient.

Dietary factors that promote obesity include high-calorie beverages (sugared soft drinks or fruit juice), energy-dense foods (fast foods, snack foods), excess refined carbohydrates, excess dietary fat, and large portion sizes (Trost, et al., 2001). The increase in the prevalence of obesity has coincided with an increase in portion sizes of foods both inside and outside the home, which suggests that larger portions may play a role in the obesity epidemic. Nutritional factors inherent in fast food, such as low levels of dietary fiber, high palatability, high energy density, high fat content, high glycaemic load, and high content of sugar in liquid form, may promote excess energy intake (Astrup, 2001). Dietary treatment plan and to provide adequate education, counseling by a health professional with expertise in dietary management is often required. Physicians usually do not have adequate time to devote to dietary management, and they may not have the expertise required. The use of a qualified and experienced health professional, preferably a registered dietitian, for dietary counseling and to implement an optimal dietary plan for achieving and maintaining a healthy body weight is recommended.

Diets with a strict limitation of energy intake leading to semi starvation should be strictly avoided because of serious health hazards that relate to deficiencies of several nutrients. Exaggerated lipid mobilization accompanied by an increased level of free fatty acids, together with a lack of essential amino acids and potassium and magnesium deficiencies might promote life-threatening cardiac arrhythmias (Fisler, 1997). The fundamental cause of obesity is greater imbalance between energy intake and expenditure than is expected for normal growth and development. Usually, this occurs over a period of time and in the setting of a susceptible genetic background and environmental factors (Frontera, et al., 2008).

A low-energy diet recommended for the treatment of obesity should be low fat $(<30 \%)$, high carbohydrate $(\sim 55 \%$ of daily energy intake), high protein (up to $25 \%$ of daily energy intake), and high fiber ( $25 \mathrm{~g} /$ day). A high-carbohydrate low-fat energy-deficient diet is usually recommended for weight management by medical societies and health authorities (Hainer, et al., 2004).

Increased content of protein in a diet contributes to better weight loss maintenance because proteins are more satiating and thermogenic than carbohydrates and fats (Westerterp-Planteng, et al., 2004) demonstrated that high protein intake sustained weight maintenance after very-low-calorie diet (VLCD)-induced weight loss. Studies made on the role of foods with a low glycaemic index and the role of increased calcium intake in reducing fat stores in human obesity have so far brought conflicting results (Diaz, et al., 2006; Thompson, et al., 2005 and Zemel, 2004).

It should be considered that the ratio between saturated, monounsaturated, and polyunsaturated fatty acids in ingested fats influences metabolic and cardiovascular risks of obesity including insulin resistance. In a recent statement, the American Diabetes Association recommends to limit an intake of saturated fats to $<7 \%$ of total calories and to minimize an intake of Trans fat.

Low-carbohydrate diets can be generally recommended to promote weight loss. No trials of low-carbohydrate diets have been performed that are powered for clinical end points (eg, myocardial infarction or death). It is therefore uncertain whether the beneficial effects of these diets on HDL-C and triglyceride levels out weigh the unfavorable changes in LDL-C level. In contrast, trials of reduced-fat diets, in conjunction with other lifestyle modifications such as increased physical activity, have demonstrated long-term maintenance of weight reduction and delayed onset of diabetes (Knowler, et al., 2002\& Tuomilehto, et al., 2001) Furthermore, randomized controlled trials have also demonstrated the benefits of the Mediterranean diet on secondary prevention of cardiovascular disease (Parikh, et al.,2005). Several studies evaluated the role of low-carbohydrate diets in weight management (Nordmann, et al., 2006). These diets have been advocated because they induce many favorable effects such as a rapid weight loss, a decrease of serum insulin and triglyceride levels, and a reduction of blood pressure as well as a higher suppression of appetite (partly due to ketogenesis, partly due 
to a higher protein intake). However, several unfavorable effects of low-carbohydrate diet administration have been demonstrated, such as an increased loss of lean body mass, increased levels of LDL cholesterol and uric acid, and an increased urinary calcium excretion. An extremely low intake of carbohydrate may lead to an unwanted energetic efficiency

Vitamins, minerals, and trace elements are added to cover recommended daily allowances (Gilden and Wadden, 2006). Inadequate intake of this essential mineral can affect on over 200 enzymes in the body, such as, alkaline phosphates (Reusser and McCarron, 1994). Prospective studies of preschool-aged children confirmed that greater longitudinal intake of calcium was associated with lower body fat (Skinner et al., 2003).

B complex vitamins help produce energy and relieve stress and depression. Lecithin enables fats, such as cholesterol, to be liquefied and expelled from the body (Reusser and McCarron, 1994).

Researchers at the National Institute of Food and Nutrition in Warsaw studied 102 overweight women and found that the women had significantly lower levels of the antioxidant vitamins $\mathrm{C}$ and $\mathrm{E}$, as well as of vitamin $\mathrm{A}$, and a higher prevalence of overall vitamin deficiency than those of normal weight.

Insulin resistance represents a serious and common complication of obesity during childhood and adolescence (Chiarelli and Marcovecchio, 2008). Fasting glucose greater than $100 \mathrm{mg} / \mathrm{dL}$ is considered peripatetic, and a level greater than or equal to $126 \mathrm{mg} / \mathrm{dL}$ is consistent with the diagnosis of diabetes. The American Diabetes Association recommends a fasting plasma glucose measurement for children aged 10 years or older who have a BMI at or above the 85th percentile and 2 of the following risk factors: a family history of type 2 diabetes mellitus in first- or seconddegree relatives, nonwhite race, and conditions associated with insulin resistance.

Fasting serum triglyceride levels are often elevated in obesity and are considered an early sign of metabolic syndrome. Children with total triglyceride levels greater than $200 \mathrm{mg} / \mathrm{dL}$ (to convert to $\mathrm{mmol} / \mathrm{L}$, multiply by 0.0113 ) should be followed up closely. Obese children should be referred to a gastroenterologist to be evaluated for nonalcoholic fatty liver disease and other chronic liver diseases (VIBHA SINGHAL, et al., 2007).

This energetic efficiency is due to the suppression of the sympathetic nervous activity and to the development of low $\mathrm{T}_{3}$ syndrome. Long-term studies are needed to evaluate the overall changes in nutritional status, body composition, metabolic health risks, and adverse events in response to lowcarbohydrate diets. Without that evaluation, low-carbohydrate diets cannot be recommended (Astrup, et al., 2004).

Chromium is an essential mineral to maintain good health. The metabolism of lipids and glucose is dependent on chromium, which helps the body maintain healthy energy levels (Cefalu, et al., 2002). Chromium is a potent metabolic hormone that aids in the breakdown and distribution of protein and carbohydrates so the body can use those fuels efficiently. Weight loss is promoted when chromium is taken. Chromium supports normal thyroid hormone, which regulates the body's ability to burn calories. It also alters the metabolism of serotonin, a neurotransmitter that controls the appetite and curbs cravings for sugar. Chromium works best if taken before meals to help maintain normal blood sugar level (Anderson, 2000).

Zinc deficiency can directly affect cognitive and perceptual processes that help maintain these insidious eating disorders. Recently it has been shown that there is an inverse relationship between morbid obesity and zinc, meaning that the more morbidly obese the individual the lower their zinc status. This suggests that zinc plays an important role in the entire continuum of eating disorders, from obesity to anorexia nervosa (Reusser and McCarron, 1994).

\section{Conclusion:}

Obesity treatment should be individually tailored and the age, sex, degree of obesity, individual health risks, metabolic and psychobehavioral characteristics, and outcome of previous weight loss attempts should be taken into account. In the future, hormonal and hereditary factors affecting weight loss should also be considered. 
The good news is that schools can help students and staff adopts healthy eating and physical activity behaviors that are the keys to preventing obesity.

\section{References:}

- Aboderin, I. (2002): Life course perspectives on coronary heart disease, stroke and diabetes: the evidence and implications for policy and research. Geneva, World Health Organization,

- Anderson, RA. (2000): Chromium in the prevention and control of diabetes. Diabetes \& Metabolism. 26(1):22-7.

- Astrup, A. (2001): The role of dietary fat in the prevention and treatment of obesity. Efficacy and safety of low-fat diets. Int $\mathrm{J}$ Obes Relat Metab Disord; 25: (1) S46-S50.

-Astrup A, Meinert Larsen T, Harper A. (2004): Atkins and other low-carbohydrate diets: hoax or an effective tool for weight loss? Lancet 364: 897899.

-Barlow, SE, Dietz, WH. (1998): Obesity evaluation and treatment: Expert Committee recommendations. Pediatrics; 102(3):E29.

- Burger H.G. and Patel Y.C. (1977): Thyrotropin releasing hormone-TSH Clinic. Endocrinol. and Metab. ,6: 831

- Burke V, Beilin LJ, and Dunbar, D. (2001): Family lifestyle and parental body mass index as predictors of body mass index in Australian children: a longitudinal study. Int J Obes Relat Metab Disord; 25: 147-157

-Chiarelli, F. and Marcovecchio, M., L., (2008): Insulin resistance and obesity in childhood European Journal of Endocrinology; 159: S67-S74.

Chinn, S. and Rona, RJ. (2001): Prevalence and trends in overweight and obesity in three crosssectional studies of British children, $1974-94$. $\mathrm{Br}$ Med J; 322: 24- 26.

- Diaz EO., Galgani JE. and Aguirre CA.,(2006): Glycaemic index effects on fuel partitioning in humans. Obes Rev 7: 219-226.

- Epstein LH, Valoski A, Wing RR, and Mc Curley J. (1990): Ten-year follow-up of behavioral, family-based treatment for obese children. JAMA; 264:2519-2523.

- Epstein LH, Valoski A, Wing RR, and McCurley J. (1994): Ten-year outcomes of behavioral family-based treatment for childhood obesity. Health Psychol.; 13:373-383.

- Epstein LH, Roemmich JN, and Raynor HA. (2001): Behavioral therapy in the treatment of pediatric obesity. Pediatr Clin North Am.; 48:981993.
- Fisler JS.,(1997): Cardiac effects of starvation and semistarvation diets: safety and mechanisms of action. Am J Clin Nutr .,337(13):869-873.

- Fossati, P., (1982): Triglycerides were determined by the colorimetric method. Principe, L. Clin. Chem. 28:207.

- Friedwald, W.T.; Levy, R.I. and Fredrickson, D.S. (1972): Serum LDL-cholesterol (LDL-C) was calculated by equation, Clin. Chem., 18(6): 499.

- Frontera M, Dickins B, Plagge A, and Kelsey G.( 2008): Imprinted genes, postnatal adaptations and enduring effects on energy homeostasis. Adv Exp MedBiol.; 626:41- 61.

-Gibson EL, Wardle J, and Watts CJ. (1998): Fruit and vegetable consumption, nutritional knowledge and beliefs in mothers and children. Appetite; 31(2): 205-28.

- Gilden Tsai A, and Wadden T., (2006): The evolution of very low calorie diets: an up-date and metaanalysis. Obesity 14: 1283-1293.

- Gordon, T. and Amer M., (1977): Serum HDLCholesterol (HDL-C) was determined J. Med., 62:707.

- Guo, S.S., Chumlea, W.C., and Cockram, D.B. (1996): Use of statistical methods to estimate body composition. Am. J. Clin. Nutr. 64:428S-435S.

- Hainer V, Finer N, Tsigos C, Basdevant A, Carruba M, Hancu N, Mathus-Vliegen L, Schutz Y, and Zahorska-Markiewicz B,(2004): Management of obesity in adults: project for European primary care. Int J Obes 28(1): S226S231.

- Lurbe E, Torro I, Aguilar F, Alvarez J, Alcon J, Pascual JM and Redon J., (2008): Added impact of obesity and insulin resistance in nocturnal blood pressure elevsity in children and adolescents. Hypertension. (51):635-641.

- Knowler WC, Barrett-Connor E, Fowler SE, et al; (2002): Diabetes Prevention Program Research Group. Reduction in the incidence of type 2 diabetes with lifestyle intervention or metformin. $\mathrm{N}$ Engl J Med. 346:393-403.

- Nordmann AJ, Nordmann A, Briel M, Keller U, Yancy WS Jr, Brehm BJ, and Bucher HC, (2006): Effects of low-carbohydrate vs low-fat diets on weight loss and cardiovascular risk factors: a metaanalysis of randomized controlled trials. Arch Intern Med .,166: 285-293

- Ogden CL, Carroll MD, Curtin LR, McDowell MA, Tabak CJ, and Flegal KM (2006): Prevalence of overweight and obesity in the United States, 1999-2004. JAMA 295: 1549-1555.

- Ogden CL, Carroll MD, and Flegal KM., (2008): High Body Mass Index for Age among US Children and Adolescents, 2003-2006. JAMA.; 299(20):2401-2405. 
- Park,J.E and park, K. (1979): Textbook of preventive and social medicine. $7^{\text {th }}$ edition p.81.Hessers Barner Sides, Publisher.

- Parikh P, McDaniel MC, Ashen MD, et al. (2005): Diets and cardiovascular disease: an evidence-based. J Am Coll Cardiol.; 45:1379-1387.

- Pirozzo S, Summerbell C, Cameron C, and Glasziou P. (2003): Should we recommend low-fat diets for obesity? Obes Rev., 4: 83-90.

- PIXI bone densitometer. Model No. 30037. S/N 030300321346. G.E. Lunar Corporation. 726 Heartland Trail. Madison, WI 53717-1915 USA. March 2004.http://www.lunarcorp.com.

- Reusser, M.E. and McCarron, D.A., (1994): Trace Element Interactions and Balance Nutr Rev., 1994: 52: 367-375

- Skinner JD, Bounds W, Carruth BR, and Ziegler P. (2003):Longitudinal calcium intake is negatively related to children's body fat indexes. J Am Diet Assoc.;103:1626-1631.

- SPSS, Statistical (1996): Package for social science computer soft ware version 8 (USA) 1996 on an IBM, PC Computer Bailey.

- Stein EA,(1986): In textbook of clinical chemistry, NW Tietz,ed.W.B.

Saunders,Philadelphia, PP. 879-886

- Sumerbell CD, Ashton V, Campbell KJ, Edmunds L, Kelly S, and Waters E. (2003): Interventions for treating obesity in children. Cochrane Database Syst Rev.:CD001872.

- TANITA Body Composition analyzer. Model TBF-300. TANITA corporation of America Inc. 1999.

-Trinder,P. (1969). Determination of blood glucose using 4-Aminophenazone. J. Clin. Path., 22: 246.

Thomerson, D. R. and Price, W. J. (1971): Analyst of zinc and chromium,: 96, 825

- Thompson WG, Holdman NR, Janzow DJ, Slezak JM, Morris KL, and Zemel MB.,(2005): Effect of energy-reduced diets high in dairy products and fiber on weight loss in obese adults. Obes Res 13: 1344-1348,

- Tremblay MS, and Willms JD. (2000): Secular trends in the body mass index of Canadian children. Can Med Assoc J; 163: 1429-1433.
- Trost SG, Kerr LM, Ward DS, and Pate RR.( 2001): Physical activity and determinants of physical activity in obese and non-obese children. Int J Obes Relat Metab Disord; 25: 822-829.

- Tuomilehto J, Lindstrom J, Eriksson JG, et al; (2001): Finnish Diabetes Prevention Study Group. Prevention of type 2 diabetes mellitus by changes in lifestyle among subjects with impaired glucose tolerance. N Engl J Med.;344:1343-1350.

- Vibha Singhal, Mbbs; W. Frederick Schwenk, MD; and Seema Kumar, MD (2007): Evaluation and Management of Childhood and Adolescent Obesity. Mayo Clin Proc.; 82(10):1258-1264.

- Westerterp-Plantenga MS, Lejeune MP, Nijs I, van Ooijen M, and Kovacs EM.,(2004): High protein intake sustains weight maintenance after body weight loss in humans. Int J Obes 28: 57-64.

Whitaker RC, Wright JA, Pepe MS, Seidel KD, and Dietz WH. (1997): Predicting obesity in young adulthood from childhood and parental obesity. N Engl J Med;337:869-873

- WHO, World Health Organization (1985): Energy and protein requirements, report of a joint FAO/WHO/UNU Expert Consultation. Rome. World Health Organization Tech. Report series No.724. ;180.

- WHO/FAO, (1998): FAO/ WHO expert consultation on human vitamin and mineral Requirements FAO, Bangkok, Thailand- September 21-30, 1998.

- WHO. Physical statu,s (1995): The use and interpretation of anthropometry, pp. 268-369. Report of WHO Expert Committee. Technical Report Series No. 854. Geneva

- WHO, World Health Organization, (2000): Obesity: preventing and managing the giobal epidemic, WHO technical series 894.

-WHO, World Health Organization, (2003): Diet, Nutrition and the Prevention of Chronic Diseases, Geneva.

Yanovski SZ, and Sebring NG.(1994): Recorded food intake of obese women with binge eating disorder before and after weight loss. International Journal of Eating Disorders ,15(2): 135-50.

Zemel MB., (2004): Role of calcium and dairy products in energy partitioning and weight management. Am J Clin Nutr., 79: 907-912. 
Table (1) Percent distribution of Individuals according to sex, age groups, weight and sites in EL Behaira governorates.

\begin{tabular}{|c|c|c|c|c|c|c|c|}
\hline \multirow{2}{*}{ Age groups } & \multirow{2}{*}{ Site } & \multirow[t]{2}{*}{ Gender } & \multicolumn{2}{|c|}{ Normal } & \multicolumn{2}{|c|}{ Obese } & \multirow{2}{*}{ Total } \\
\hline & & & No & $\%$ & "No & $\%$ & \\
\hline \multirow{6}{*}{$6->12$} & \multirow{3}{*}{$\mathbf{U}$} & $\mathbf{B}$ & 17 & 33.3 & 24 & 48.0 & 41 \\
\hline & & $\mathbf{G}$ & 34 & 66.7 & 26 & 52.0 & 60 \\
\hline & & $\mathbf{T}$ & 51 & 100 & 50 & 100 & 101 \\
\hline & \multirow{3}{*}{$\mathbf{R}$} & B & 12 & 30.8 & 26 & 54.2 & 38 \\
\hline & & $\mathbf{G}$ & 27 & 69.2 & 22 & 45.8 & 49 \\
\hline & & $\mathbf{T}$ & 39 & 100 & 48 & 100 & 87 \\
\hline Total & & & 90 & 100 & 98 & 100 & 188 \\
\hline
\end{tabular}

$\mathrm{B}=$ Boys $\mathrm{G}=$ girls $\mathrm{T}=$ total $\mathrm{U}=$ urban $\mathrm{R}=$ rule

Table (2): Biodemographic status of children in EL Behaira governorates.

\begin{tabular}{|c|c|c|c|c|c|c|c|c|c|c|c|c|c|}
\hline \multirow{3}{*}{$\begin{array}{l}\text { Age } \\
\text { sex } \\
\end{array}$} & \multirow{3}{*}{ Family Score } & \multicolumn{6}{|c|}{ Urban } & \multicolumn{6}{|c|}{ Rural } \\
\hline & & \multicolumn{2}{|c|}{ Normal } & \multicolumn{2}{|c|}{$\bar{~} \overline{\text { Obese }}$} & \multicolumn{2}{|c|}{ Total } & \multicolumn{2}{|c|}{ Normal } & \multicolumn{2}{|c|}{ Obese } & \multicolumn{2}{|c|}{ Total } \\
\hline & & No & $\%$ & No & $\%$ & No & $\%$ & No & $\%$ & No & $\%$ & No & $\%$ \\
\hline \multirow{4}{*}{$\begin{array}{l}6-<12 \\
\text { girls }\end{array}$} & High & 0 & 0.0 & 0 & 0.0 & 0 & O & $\mathbf{0}$ & 0.0 & $\mathbf{0}$ & 0.0 & 0 & 0 \\
\hline & Moderate & 17 & 28.3 & 16 & 26.7 & 33 & 55.0 & 6 & 12.2 & 11 & 22.4 & 17 & 34.7 \\
\hline & Low & 17 & 28.3 & 10 & 16.7 & 27 & 45.0 & 21 & 42.9 & 11 & 22.4 & 32 & 65.3 \\
\hline & Total & 34 & 56.7 & 26 & 43.3 & 60 & 100 & 27 & 55.1 & 22 & 44.8 & 49 & 100 \\
\hline \multirow{5}{*}{$\begin{array}{l}6-<12 \\
\text { boys }\end{array}$} & High & $\mathbf{0}$ & 0.0 & 1 & 1.6 & 1 & 1.6 & $\mathbf{0}$ & 0.0 & $\mathbf{0}$ & 0.0 & 0 & $\mathbf{0}$ \\
\hline & Moderate & 12 & 29.3 & 17 & 41.5 & 29 & 70.7 & 5 & 13.2 & 7 & 18.4 & 12 & 31.6 \\
\hline & LLw & 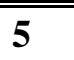 & 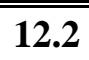 & 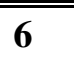 & $1 \overline{14.6}$ & 12 & 20.3 & 7 & 1818.4 & 19 & 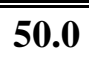 & 20 & (6804 \\
\hline & Total & 17 & $4 \mathbf{4 1 . 5}$ & 24 & 58.5 & 41 & 100 & 12 & 31.6 & 26 & 68.4 & 38 & 100 \\
\hline & Family Size & No & $\%$ & No & $\%$ & No & $\%$ & No & $\%$ & No & $\%$ & No & $\%$ \\
\hline \multirow{4}{*}{$\begin{array}{l}6-<12 \\
\text { girls }\end{array}$} & $<5$ & 17 & 28.3 & 11 & 18.3 & 28 & 46.7 & 2 & 4.1 & 6 & 12.2 & 8 & 16.3 \\
\hline & $5-9$ & 17 & 28.3 & 14 & 23.3 & 31 & 51.7 & 25 & 51.0 & 16 & 32.7 & 41 & 83.7 \\
\hline & $>9$ & $\overline{\mathbf{0}}$ & 0.0 & 1 & 1.6 & 1 & 1.6 & $\overline{\mathbf{0}}$ & 0.0 & $\overline{\mathbf{0}}$ & 0.0 & $\overline{\mathbf{0}}$ & 0.0 \\
\hline & Total & 34 & 56.7 & 26 & 43.3 & 60 & 100 & 27 & 55.1 & 22 & 44.8 & 49 & 100 \\
\hline \multirow{5}{*}{$\begin{array}{l}6-<12 \\
\text { boys }\end{array}$} & $<5$ & 6 & 14.6 & 8 & 19.5 & 14 & 34.1 & 11 & 28.9 & 11 & 28.9 & 22 & 57.9 \\
\hline & $5-9$ & 11 & 26.8 & 16 & 39.0 & 27 & 65.9 & 1 & 28.9 & 14 & 36.8 & 15 & 39.5 \\
\hline & $>9$ & $\mathbf{0}$ & 0.0 & $\mathbf{0}$ & 0.0 & $\mathbf{0}$ & 0.0 & $\mathbf{0}$ & 0.0 & 1 & 2.6 & 1 & 2.6 \\
\hline & Total & 17 & 41.5 & 24 & 58.5 & 41 & 100 & 12 & 31.6 & 26 & 68.4 & 38 & 100 \\
\hline & $\begin{array}{l}\text { Education } \\
\text { level }\end{array}$ & No & $\%$ & No & $\%$ & No & $\%$ & No & $\%$ & No & $\%$ & No & $\%$ \\
\hline
\end{tabular}




\begin{tabular}{|c|c|c|c|c|c|c|c|c|c|c|c|c|c|}
\hline \multirow{3}{*}{$\begin{array}{l}6-<12 \\
\text { girls }\end{array}$} & Illiterate & $\mathbf{0}$ & 0.0 & $\mathbf{0}$ & 0.0 & 0 & 0.0 & $\mathbf{0}$ & 0.0 & $\mathbf{0}$ & 0.0 & $\mathbf{0}$ & 0.0 \\
\hline & $\begin{array}{l}\text { Can read and } \\
\text { write only }\end{array}$ & 33 & 55.0 & 27 & 45.0 & 60 & 100 & 27 & 55.1 & 22 & 44.9 & 49 & 100 \\
\hline & Total & 33 & 55.0 & 27 & 45.0 & 60 & 100 & 27 & 55.1 & 22 & 44.9 & 49 & 100 \\
\hline \multirow{3}{*}{$\begin{array}{l}6-<12 \\
\text { boys }\end{array}$} & Illiterate & 0 & 0.0 & 0 & 0.0 & 0 & 0.0 & 0 & 0.0 & 0 & 0.0 & 0 & 0.0 \\
\hline & $\begin{array}{l}\text { Can read and } \\
\text { write only }\end{array}$ & 17 & 41.5 & 24 & 58.5 & 41 & 100 & 15 & 39.5 & 23 & 60.5 & 38 & 100 \\
\hline & Total & 17 & 41.5 & 24 & 58.5 & 41 & 100 & 15 & 39.5 & 23 & 60.5 & 38 & 100 \\
\hline
\end{tabular}

Table (3): The mean anthropometric measures in children according to age groups and sites in EL Behaira governorate.

\begin{tabular}{|c|c|c|c|c|c|}
\hline \multirow{3}{*}{$\begin{array}{l}\text { Age and } \\
\text { six }\end{array}$} & \multirow{3}{*}{$\begin{array}{l}\text { Anthropometric } \\
\text { measurements }\end{array}$} & \multicolumn{2}{|c|}{ Urban } & \multicolumn{2}{|c|}{ Rural } \\
\hline & & Normal & Obese & Normal & Obese \\
\hline & & $\begin{array}{c}\text { mean } \pm \\
\text { S.D }\end{array}$ & $\begin{array}{c}\text { mean } \pm \\
\text { S.D }\end{array}$ & $\begin{array}{c}\text { mean } \pm \\
\text { S.D }\end{array}$ & $\begin{array}{c}\text { mean } \pm \\
\text { S.D }\end{array}$ \\
\hline \multirow{3}{*}{$\begin{array}{l}\text { boys } \\
6-<12\end{array}$} & Weight & $\begin{array}{c}41.28 \pm \\
6.05\end{array}$ & $\begin{array}{c}\mathbf{5 0 . 5 2 \pm} \\
7.17\end{array}$ & $\begin{array}{c}39.71 \pm \\
6.61\end{array}$ & $\begin{array}{c}52.57 \pm \\
6.89\end{array}$ \\
\hline & Height & $\begin{array}{c}137.4 \pm \\
8.16\end{array}$ & $\begin{array}{c}136.8 \pm \\
8.37\end{array}$ & $\begin{array}{l}136.1 \pm \\
8.86\end{array}$ & $\begin{array}{c}138.4 \pm \\
13.21\end{array}$ \\
\hline & $\begin{array}{l}\text { Weight/ height } \\
\text { Z. score }\end{array}$ & $\begin{array}{c}1.27 \pm \\
0.4\end{array}$ & $\begin{array}{c}4.35 \pm \\
0.83\end{array}$ & $\begin{array}{l}1.01 \pm \\
0.6\end{array}$ & $\begin{array}{l}4.35 \pm \\
0.59\end{array}$ \\
\hline \multirow{3}{*}{$\begin{array}{l}\text { girls } \\
6-<12\end{array}$} & Weight & $\begin{array}{c}41.31 \pm \\
7.09\end{array}$ & $\begin{array}{c}53.37 \pm \\
12.10\end{array}$ & $\begin{array}{l}43.11 \pm \\
5.88\end{array}$ & $\begin{array}{c}48.24 \pm \\
9.96\end{array}$ \\
\hline & Height & $\begin{array}{c}137.8 \pm \\
9.89\end{array}$ & $\begin{array}{c}138.3 \pm \\
11.03\end{array}$ & $\begin{array}{c}138.8 \pm \\
7.09\end{array}$ & $\begin{array}{c}131.7 \pm \\
11.13\end{array}$ \\
\hline & $\begin{array}{l}\text { Weight/ height } \\
\text { Z. score }\end{array}$ & $\begin{array}{c}1.28 \pm \\
0.54\end{array}$ & $\begin{array}{c}3.7 \pm \\
0.6\end{array}$ & $\begin{array}{c}1.18 \pm \\
0.6\end{array}$ & $\begin{array}{l}4.1 \pm \\
0.8\end{array}$ \\
\hline
\end{tabular}

Table (4) Percent of distribution of the individual opinion about the main factor related to obesity according to site and age for children in EL Behaira governorates

\begin{tabular}{|c|c|c|c|c|c|c|c|c|c|c|c|c|c|}
\hline \multirow{3}{*}{ Age } & \multirow{3}{*}{ Factors } & \multicolumn{6}{|c|}{ Urban } & \multicolumn{6}{|c|}{ Rural } \\
\hline & & \multicolumn{2}{|c|}{ Normal } & \multicolumn{2}{|c|}{ Obese } & \multicolumn{2}{|c|}{ Total } & \multicolumn{2}{|c|}{ Normal } & \multicolumn{2}{|c|}{ Obese } & \multicolumn{2}{|c|}{ Total } \\
\hline & & No & $\%$ & No & $\%$ & No & $\%$ & No & $\%$ & No & $\%$ & No & $\%$ \\
\hline \multirow{4}{*}{$\begin{array}{l}\text { boys } \\
6-<12\end{array}$} & Diet & 16 & 39.0 & 21 & 51.2 & 37 & 90.2 & 11 & 28.9 & 22 & 57.9 & 33 & 86.8 \\
\hline & Drugs & $\mathbf{0}$ & 0.0 & $\mathbf{0}$ & 0.0 & $\mathbf{0}$ & $\mathbf{0}$ & $\mathbf{0}$ & 0.0 & $\mathbf{0}$ & 0.0 & $\mathbf{0}$ & $\mathbf{0}$ \\
\hline & Low physical activity & 2 & 4.9 & 2 & 4.9 & 4 & 9.8 & 2 & 5.2 & 3 & 7.9 & 5 & 13.2 \\
\hline & Total & 18 & 43.9 & 23 & 56.1 & 41 & 100 & 13 & 34.2 & 25 & 65.8 & 38 & 100 \\
\hline \multirow{4}{*}{$\begin{array}{c}\text { Girls } \\
6-<12\end{array}$} & Diet & 26 & 43.3 & 22 & \begin{tabular}{|l|l}
36.7 \\
\end{tabular} & 48 & 80.0 & 22 & 44.9 & 17 & 34.7 & 39 & 79.6 \\
\hline & Drugs & $\mathbf{0}$ & 0.0 & $\mathbf{0}$ & 0.0 & $\mathbf{0}$ & $\mathbf{0}$ & $\mathbf{0}$ & 0.0 & $\mathbf{0}$ & 0.0 & $\mathbf{0}$ & $\mathbf{0}$ \\
\hline & Low physical activity & 6 & 10.0 & 6 & 10.0 & 12 & 20.0 & 7 & 14.3 & 3 & 6.1 & 10 & 20.4 \\
\hline & Total & 32 & 53.3 & 28 & 46.7 & 60 & 100 & 29 & 59.2 & 20 & 40.8 & 49 & 100 \\
\hline
\end{tabular}


Table (5) Percent of distribution of individual's opinions of diets related to obesity according to age and body weight by site of children in EL Behaira governorates.

\begin{tabular}{|c|c|c|c|c|c|c|c|c|c|c|c|c|c|}
\hline \multirow{3}{*}{ Age } & \multirow{3}{*}{$\begin{array}{l}\text { Family history of } \\
\text { certain disease }\end{array}$} & \multicolumn{6}{|c|}{ Urban } & \multicolumn{6}{|c|}{ Rural } \\
\hline & & \multicolumn{2}{|c|}{ Normal } & \multicolumn{2}{|c|}{ Obese } & \multicolumn{2}{|c|}{ 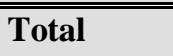 } & \multicolumn{2}{|c|}{ Normal } & \multicolumn{2}{|c|}{$\begin{array}{l}\text { Obese } \\
\text { Obe }\end{array}$} & \multicolumn{2}{|c|}{ 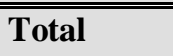 } \\
\hline & & No & $\%$ & No & $\%$ & No & $\%$ & No & $\%$ & No & $\%$ & No & $\%$ \\
\hline \multirow{11}{*}{$\begin{array}{l}\text { boys } \\
6<12\end{array}$} & Carbohydrates & 1 & 2.4 & 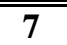 & $\overline{c 17.1}$ & 8 & 19.5 & 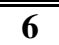 & $\overline{15.8}$ & 111 & 28.9 & 17 & 444.7 \\
\hline & Sweets & 3 & 7.3 & 10 & 24.4 & 13 & 31.7 & 2 & 5.3 & 7 & 18.4 & 9 & 23.7 \\
\hline & Fats & $\overline{3}$ & 7.3 & $\overline{0}$ & $\overline{0.0}$ & $\overline{3}$ & 7.3 & $\overline{11}$ & 2.6 & 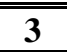 & 7.9 & 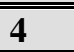 & $\mathbf{1 0 . 5}$ \\
\hline & Fast food & 1 & 2.4 & 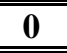 & $\begin{array}{l}0.0 \\
\end{array}$ & 1 & 2.4 & $\overline{0}$ & $\overline{0.0}$ & 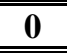 & 0.0 & $\mathbf{0}$ & 0.0 \\
\hline & Soft drinks & $\begin{array}{c}\mathbf{0} \\
\end{array}$ & $\begin{array}{ll}0.0 \\
\end{array}$ & $\overline{0}$ & $\overline{0.0}$ & $\overline{0}$ & 0.0 & $\overline{0}$ & $\begin{array}{ll}0.0 \\
\end{array}$ & $\overline{0}$ & 0.0 & $\overline{0}$ & $\begin{array}{c}0.0 \\
\end{array}$ \\
\hline & Nuts & 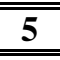 & 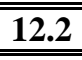 & $\overline{\mathbf{0}}$ & 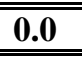 & $\overline{5}$ & 12.2 & 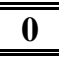 & 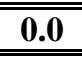 & $\begin{array}{l}\mathbf{0} \\
\end{array}$ & 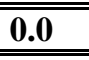 & $\overline{\overline{\mathbf{0}}}$ & 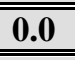 \\
\hline & Fruit vegetables & $\overline{0}$ & $\overline{0.0}$ & 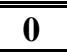 & $\overline{0.0}$ & 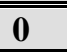 & 0.0 & $\overline{\mathbf{0}}$ & 0.0 & 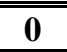 & $\overline{0.0}$ & $\overline{0}$ & 0.0 \\
\hline & proteins & $\overline{0} \mathbf{0}$ & 0.0 & 3 & 7.3 & 3 & 7.3 & 2 & 5.3 & $\mathbf{0}$ & 0.0 & $\mathbf{0}$ & $\overline{0.0}$ \\
\hline & Juices & 2 & 4.9 & $\begin{array}{l}\mathbf{0} \\
\end{array}$ & 0.0 & 2 & $\begin{array}{l}4.9 \\
\end{array}$ & $\overline{1}$ & $\overline{2.6}$ & $\begin{array}{l}\mathbf{0} \\
\end{array}$ & 0.0 & 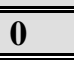 & $\begin{array}{c}0.0 \\
\end{array}$ \\
\hline & $\begin{array}{c}\text { food between } \\
\text { meals }\end{array}$ & $\mathbf{0}$ & 0.0 & 6 & 14.6 & 6 & 14.6 & $\mathbf{0}$ & 0.0 & 5 & 13.2 & 5 & 13.2 \\
\hline & $\begin{array}{l}\text { Total } \\
\end{array}$ & 15 & 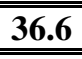 & 26 & 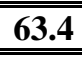 & $\begin{array}{ll}41 \\
\end{array}$ & 100 & 12 & $\begin{array}{c}31.6 \\
\end{array}$ & 26 & 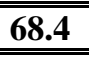 & 38 & 100 \\
\hline \multirow{11}{*}{ girls } & Carbohydrates & 4 & 6.7 & 7 & 11.7 & 11 & 18.3 & 11 & 22.4 & 6 & 12.2 & 17 & 34.7 \\
\hline & Sweets & 14 & 23.3 & 11 & 18.3 & 25 & 41.7 & 7 & 14.3 & 7 & 14.3 & 14 & 28.6 \\
\hline & Fats & 8 & 13.3 & 4 & $\begin{array}{l}6.7 \\
\end{array}$ & 12 & 20.0 & 5 & 10.2 & 3 & 6.1 & 8 & 10.3 \\
\hline & Fast food & 1 & 1.7 & 1 & $\begin{array}{l}1.7 \\
\end{array}$ & 2 & $\begin{array}{l}3.3 \\
\end{array}$ & 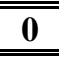 & 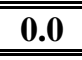 & 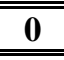 & 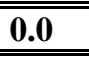 & 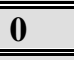 & 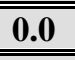 \\
\hline & Soft drinks & $\overline{1}$ & 1.7 & $\overline{\mathbf{0}}$ & 0.0 & 1 & 1.7 & $\overline{\mathbf{0}}$ & 0.0 & $\overline{\mathbf{0}}$ & $\overline{0.0}$ & $\overline{\mathbf{0}}$ & 0.0 \\
\hline & Nuts & 1 & 1.7 & $\mathbf{0}$ & 0.0 & 1 & 1.7 & $\overline{\mathbf{0}}$ & 0.0 & $\mathbf{0}$ & 0.0 & $\overline{\mathrm{O}}$ & 0.0 \\
\hline & Fruit vegetables & 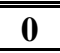 & 0.0 & $\overline{0}$ & 0.0 & 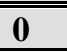 & 0.0 & 2 & 4.1 & 1 & 2.0 & 3 & 6.1 \\
\hline & proteins & 4 & 6.7 & 2 & 3.3 & 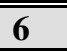 & 10.0 & 1 & 2.0 & 5 & 10.2 & $\overline{66}$ & 12.2 \\
\hline & Juices & 1 & $\begin{array}{l}1.7 \\
\end{array}$ & $\overline{\mathbf{0}}$ & $\begin{array}{l}0.0 \\
\end{array}$ & 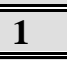 & $\begin{array}{l}1.7 \\
\end{array}$ & 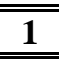 & $\begin{array}{l}2.0 \\
\end{array}$ & $\overline{\mathbf{0}}$ & $\overline{0.0}$ & $\overline{1}$ & 2.0 \\
\hline & $\begin{array}{c}\text { food between } \\
\text { meals }\end{array}$ & $\mathbf{0}$ & 0.0 & 1 & 1.7 & 1 & 1.7 & $\mathbf{0}$ & 0.0 & $\mathbf{0}$ & 0.0 & 0 & 0.0 \\
\hline & Total & $\begin{array}{l}34 \\
\end{array}$ & & 26 & & 60 & 100 & 27 & $\begin{array}{l}55.1 \\
\end{array}$ & 22 & $\begin{array}{c}44.9 \\
\end{array}$ & 4 & $\begin{array}{l}100 \\
\end{array}$ \\
\hline
\end{tabular}


Table (6) Distribution of boys 6-12 y according to dietary habits in total sample in Behaira governorate

\begin{tabular}{|c|c|c|c|c|c|c|c|c|c|c|c|c|}
\hline \multirow{3}{*}{ Dietary habits } & \multicolumn{4}{|c|}{ urban } & \multirow{2}{*}{\multicolumn{2}{|c|}{ Total }} & \multicolumn{4}{|c|}{ rural } & \multirow{2}{*}{\multicolumn{2}{|c|}{ Total }} \\
\hline & \multicolumn{2}{|c|}{ Normal } & \multicolumn{2}{|c|}{ Obese } & & & \multicolumn{2}{|c|}{ Normal } & \multicolumn{2}{|c|}{ Obese } & & \\
\hline & No & $\%$ & No & $\%$ & No & $\%$ & No & $\%$ & No & $\%$ & No & $\%$ \\
\hline \multicolumn{13}{|l|}{ No of meals } \\
\hline 1 & 1 & 2.4 & - & - & 1 & 2.4 & - & - & - & - & - & - \\
\hline 2 & 7 & 17.1 & 7 & 17.1 & 14 & 34.1 & 3 & 7.9 & 7 & 18.4 & 10 & 26.3 \\
\hline 3 & 4 & 9.8 & 16 & 39.0 & 20 & 48.9 & 9 & 23.7 & 18 & 47.4 & 27 & 71.1 \\
\hline$>3$ & 5 & 12.2 & 1 & 2.4 & 6 & 14.6 & - & - & 1 & 2.6 & 1 & 2.6 \\
\hline Total & 17 & 41.5 & 24 & $\mathbf{5 8 . 5}$ & 41 & 100 & 12 & 31.6 & 26 & $\begin{array}{l}68.4 \\
\end{array}$ & 38 & 100 \\
\hline \multicolumn{13}{|l|}{ Main meals } \\
\hline Breakfast & 1 & 2.4 & 1 & 2.4 & 2 & 4.9 & - & - & 1 & 2.6 & 1 & 2.6 \\
\hline Lunch & 14 & 34.1 & 22 & 53.7 & 36 & 87.8 & 11 & 28.9 & 23 & 60.5 & 34 & 89.5 \\
\hline dinner & 2 & 4.9 & 1 & 2.4 & 3 & 7.3 & 1 & 2.6 & 2 & 5.3 & 3 & 7.9 \\
\hline Total & 17 & 41.5 & 24 & 58.5 & 41 & 100 & 12 & 31.6 & 26 & $\begin{array}{l}68.4 \\
\end{array}$ & 38 & 100 \\
\hline \multicolumn{13}{|c|}{ Snacks in between meals } \\
\hline Yes & 13 & 31.7 & 19 & 46.3 & 32 & 78.0 & 10 & 26.3 & 22 & 57.9 & 32 & 84.2 \\
\hline No & 4 & 9.8 & 5 & $\mathbf{1 2 . 2}$ & 9 & 22.0 & 2 & 5.3 & 4 & 10.5 & 6 & 15.8 \\
\hline Total & 17 & 41.5 & 24 & $\mathbf{5 8 . 5}$ & 41 & 100 & 12 & 31.6 & 26 & 68.4 & 38 & 100 \\
\hline \multicolumn{13}{|c|}{ Eating during T.V. watching } \\
\hline Yes & 12 & 29.3 & 17 & 41.5 & 29 & 70.7 & 9 & 23.7 & 16 & 42.1 & 25 & 65.8 \\
\hline No & 5 & $\mathbf{1 2 . 2}$ & 7 & 17.1 & 12 & 29.3 & 3 & 7.9 & 10 & 26.3 & 13 & 34.2 \\
\hline Total & 17 & 41.5 & 24 & $\mathbf{5 8 . 5}$ & 41 & 100 & 12 & 31.6 & 26 & 68.4 & 38 & 100 \\
\hline \multicolumn{13}{|c|}{ Consuming fast food } \\
\hline Yes & 7 & $\mathbf{1 7 . 1}$ & 7 & $\mathbf{1 7 . 1}$ & 14 & 34.1 & 3 & 7.9 & 9 & 23.7 & 12 & 31.5 \\
\hline No & 10 & 24.4 & 17 & 41.5 & 27 & 65.9 & 9 & 23.9 & 17 & 44.7 & 26 & 68.5 \\
\hline Total & 17 & 41.5 & 24 & $\mathbf{5 8 . 5}$ & 41 & 100 & 12 & 31.6 & 26 & 68.4 & 38 & 100 \\
\hline $\begin{array}{l}\text { Type of food buy } \\
\text { at school }\end{array}$ & \multicolumn{2}{|c|}{4 boys } & \multicolumn{2}{|c|}{10 boys } & 14 & 100 & \multicolumn{2}{|c|}{6 boys } & \multicolumn{2}{|c|}{8 boys } & 14 & 100 \\
\hline Beverage & - & - & 1 & 10 & 1 & 7.1 & 2 & 33.3 & - & - & 2 & 14.3 \\
\hline Chips & 1 & 25 & 2 & 20 & 3 & 21.4 & 1 & 16.7 & 2 & 25 & 1 & 7.1 \\
\hline Koshari & - & - & - & - & - & - & - & - & 1 & 12.5 & 1 & 7.1 \\
\hline Molto & 1 & 25 & - & - & 1 & 7.1 & - & - & - & - & - & - \\
\hline Pizza & - & - & - & - & - & - & - & - & 2 & 25 & 2 & 14.3 \\
\hline Buiscite & - & - & 6 & 60 & 6 & 42.9 & 2 & 33.3 & 1 & 12.5 & 3 & 21.4 \\
\hline Homos & - & - & - & - & - & - & - & - & - & - & - & - \\
\hline Termis & - & - & - & - & - & - & - & - & - & - & - & - \\
\hline Nuts & - & - & 1 & 10 & 1 & 7.1 & - & - & 2 & 25 & 2 & 14.3 \\
\hline chocolate & 2 & 50 & - & - & 2 & 14.3 & 1 & $\begin{array}{ll}16.7 \\
\end{array}$ & - & - & 1 & 7.1 \\
\hline
\end{tabular}


Table (7) Distribution of girls 6-12 y according to dietary habits in total sample in El Behaira governorate.

\begin{tabular}{|c|c|c|c|c|c|c|c|c|c|c|c|c|}
\hline \multirow{3}{*}{ Dietary habits } & \multicolumn{6}{|c|}{ urban } & \multicolumn{6}{|c|}{ rural } \\
\hline & \multicolumn{2}{|c|}{ Normal } & \multicolumn{2}{|c|}{$\begin{array}{l}\text { Obese } \\
\end{array}$} & \multicolumn{2}{|c|}{$\overline{\text { Total }}$} & \multicolumn{2}{|c|}{ Normal } & \multicolumn{2}{|c|}{$\begin{array}{l}\text { Obese } \\
\end{array}$} & \multicolumn{2}{|c|}{$\overline{\text { Total }}$} \\
\hline & No & $\%$ & No & $\%$ & No & $\%$ & No & $\%$ & No & $\%$ & No & $\%$ \\
\hline \multicolumn{13}{|l|}{ No of meals } \\
\hline 1 & 1 & 1.7 & 1 & 1.7 & 2 & 3.3 & - & - & - & - & - & - \\
\hline 2 & 9 & 15.0 & 7 & 27 & 16 & 26.7 & 5 & 18.5 & 3 & 13.6 & 8 & 16.3 \\
\hline 3 & 21 & $\begin{array}{l}35.0 \\
\end{array}$ & 15 & $\bar{~} 57.7$ & 36 & $\overline{c 60.0}$ & 20 & $\begin{array}{l}74.1 \\
\end{array}$ & 16 & 72.7 & 36 & 73.5 \\
\hline$>3$ & 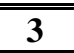 & $\mathbf{5 . 0}$ & 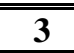 & 11.5 & 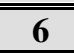 & 10.0 & 2 & 7.4 & 3 & 13.6 & $\overline{5}$ & 10.2 \\
\hline Total & 34 & 56.7 & 26 & $\begin{array}{l}43.3 \\
\end{array}$ & 60 & 100 & 27 & 55.1 & 22 & 444.9 & 49 & 100 \\
\hline \multicolumn{13}{|l|}{ Main meals } \\
\hline Breakfast & 2 & 3.3 & 1 & $\overline{1.7}$ & 3 & $\overline{5.0}$ & 3 & 11.1 & 2 & 9.1 & 5 & 10.2 \\
\hline Lunch & 28 & 46.7 & 21 & 35.0 & 49 & 81.7 & 21 & 777.8 & 17 & 77.3 & 38 & 77.6 \\
\hline dinner & 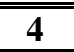 & 6.7 & 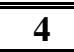 & 6.7 & 8 & 13.3 & $\overline{3}$ & 111.1 & 3 & 13 13.6 & 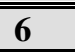 & 12.2 \\
\hline Total & 34 & 56.7 & 26 & 43.3 & 60 & 100 & 27 & 55.1 & 22 & 444.9 & 49 & 100 \\
\hline \multicolumn{13}{|c|}{ Snacks in between meals } \\
\hline Yes & 29 & 85.3 & 21 & 80.8 & $\mathbf{5 0}$ & 83.3 & 25 & 92.6 & 19 & 86.4 & 44 & 89.8 \\
\hline No & 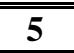 & 14.7 & $\overline{5}$ & 19.2 & 10 & 16.7 & 2 & 7.4 & 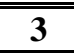 & 13 13.6 & $\overline{5}$ & 10.2 \\
\hline Total & 34 & 56.7 & 26 & 43.3 & 60 & 100 & 27 & 55.1 & 22 & 44.9 & 49 & 100 \\
\hline \multicolumn{13}{|c|}{ Eating during T.V. watching } \\
\hline Yes & $2 \mathbf{2 3}$ & 67.6 & 12 & 40.2 & 35 & $\begin{array}{c}58.3 \\
\end{array}$ & 18 & 66.7 & 15 & 68.2 & 33 & 67.3 \\
\hline No & 11 & 32.4 & 14 & 53.8 & 25 & 41.7 & 9 & 33.3 & 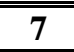 & 31.8 & 16 & 32.7 \\
\hline Total & 34 & 56.7 & 26 & ב43.3 & 60 & 10 & 27 & $\begin{array}{l}55.1 \\
\end{array}$ & 22 & 444.9 & 49 & 100 \\
\hline \multicolumn{13}{|c|}{ Consuming fast food } \\
\hline Yes & 12 & 35.3 & 11 & 42.3 & 23 & 38.3 & 7 & 25.9 & 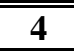 & 18.2 & 11 & 22.4 \\
\hline No & 22 & 64.7 & 15 & ב57.7 & 37 & 61.7 & 20 & & 18 & & 38 & 77.6 \\
\hline Total & 34 & 56.7 & 26 & 43.3 & 60 & 100 & 27 & 55.1 & 22 & 44.9 & 49 & 100 \\
\hline $\begin{array}{l}\text { Type of food buy } \\
\text { at school }\end{array}$ & \multicolumn{2}{|c|}{7 girls } & \multicolumn{2}{|c|}{15 girls } & 21 & 100 & \multicolumn{2}{|c|}{11 girls } & \multicolumn{2}{|c|}{12 girls } & 23 & 100 \\
\hline "Beverage & 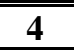 & $\begin{array}{c}57.1 \\
\end{array}$ & 1 & 12.5 & 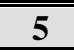 & 23.8 & 1 & 9.1 & $\begin{array}{l}3 \\
\end{array}$ & 25 & 4 & 17.4 \\
\hline "Chips & - & 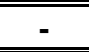 & 5 & 62.5 & 5 & 23.8 & 3 & 27.2 & 2 & 16.7 & 5 & 21.7 \\
\hline Koshari & - & 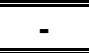 & 1 & 12.5 & $\overline{1} 1$ & 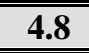 & 1 & 9.1 & $\overline{1} 1$ & 8.3 & 2 & 8.7 \\
\hline "Molto & - & 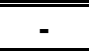 & 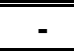 & - & 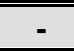 & - & 1 & 9.1 & $\overline{1} 1$ & 8.3 & 2 & 8.7 \\
\hline Pizza & $\overline{1}$ & 14.3 & - & - & 1 & 4.8 & 1 & 9.1 & - & - & 1 & 4.3 \\
\hline Buiscite & 2 & 28.6 & 1 & 12.5 & 3 & 14.3 & 2 & 18.2 & 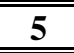 & 441.7 & 7 & 30.4 \\
\hline Homos & - & - & - & - & - & - & - & - & - & - & - & - \\
\hline Termis & - & - & - & - & - & - & - & - & - & - & - & - \\
\hline Nuts & - & - & - & - & 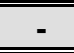 & - & 2 & 18.2 & - & - & 2 & 8.7 \\
\hline chocolate & - & - & - & - & - & - & - & - & - & - & - & - \\
\hline
\end{tabular}


Table (8) Mean Energy and selected macronutrients intake $\pm S D$ per day among Boys 6-<12 years in the different study groups in EL Behaira governorates

\begin{tabular}{|c|c|c|c|c|c|c|}
\hline \multirow{3}{*}{ Variables } & \multicolumn{3}{|c|}{ Urban } & \multicolumn{3}{|c|}{ Rural } \\
\hline & Normal (17) & Obese (24) & $\begin{array}{l}\text { Total } \\
(41)\end{array}$ & $\begin{array}{c}\text { Normal } \\
(12)\end{array}$ & Obese (26) & $\begin{array}{c}\begin{array}{c}\text { Total } \\
(38)\end{array} \\
\end{array}$ \\
\hline & $\begin{array}{c}\text { mean } \pm \\
\text { SD }\end{array}$ & mean \pm SD & mean \pm SD & mean \pm SD & $\begin{array}{c}\text { mean } \pm \\
\text { SD }\end{array}$ & mean \pm SD \\
\hline Energy (Kcal) intake & $\begin{array}{c}2460 \pm \\
325.0\end{array}$ & $\begin{array}{l}3350.0 \pm \\
441.2\end{array}$ & $\begin{array}{c}2905 \pm \\
383\end{array}$ & $\begin{array}{l}2531 \pm \\
330.4\end{array}$ & $3361 \pm 441.0$ & $\begin{array}{l}2946 \pm \\
385.5\end{array}$ \\
\hline Mean RDA (Kcal) & 2250 & 2250 & 2250 & 2250 & 2250 & 2250 \\
\hline \% intake from RDA & $109.3 \%$ & $148.9 \%$ & $129.1 \%$ & $112.5 \%$ & $149.4 \%$ & $131 \%$ \\
\hline Total protein (g) intake & $\begin{array}{c}93.7 \pm \\
14.6\end{array}$ & $\begin{array}{c}123.9 \pm \\
25.0\end{array}$ & $\begin{array}{c}108.8 \pm \\
19.1\end{array}$ & $\begin{array}{c}99.6 \pm \\
8.4\end{array}$ & $\begin{array}{c}110.4 \pm \\
20.1\end{array}$ & $\begin{array}{c}105.0 \pm \\
14.0\end{array}$ \\
\hline RDA for protein /g & 36.5 & 36.5 & 36.5 & 36.5 & 36.5 & 36.5 \\
\hline \% intake from RDA & $256.7 \%$ & $339.5 \%$ & $298.1 \%$ & $272.9 \%$ & $302.5 \%$ & $287.7 \%$ \\
\hline Total fat (g) intake & $\begin{array}{l}90.1 \pm \\
11.5\end{array}$ & $\begin{array}{c}122.3 \pm \\
23.0\end{array}$ & $\begin{array}{c}106.2 \pm \\
17.2 \\
\end{array}$ & $\begin{array}{l}92.2 \pm \\
12.5\end{array}$ & $\begin{array}{c}124.0 \pm \\
14.1 \\
\end{array}$ & $\begin{array}{c}108.1 \pm \\
21.3 \\
\end{array}$ \\
\hline Cholesterol (mg) intake & $\begin{array}{c}200.3 \pm \\
17.7 \\
\end{array}$ & $\begin{array}{c}363.3 \pm \\
29.5 \\
\end{array}$ & $\begin{array}{c}281.8 \pm \\
20.2 \\
\end{array}$ & $\begin{array}{c}201.9 \pm \\
16.7 \\
\end{array}$ & $\begin{array}{c}297.1 \pm \\
20.6 \\
\end{array}$ & $\begin{array}{c}249.5 \pm \\
18.0 \\
\end{array}$ \\
\hline Carbohydrates (g) intake & $\begin{array}{l}318.5 \pm \\
27.7\end{array}$ & $\begin{array}{l}438.6 \pm \\
16.4\end{array}$ & $\begin{array}{c}378.5 \pm \\
14.1\end{array}$ & $\begin{array}{l}326.1 \pm \\
13.6\end{array}$ & $\begin{array}{l}450.9 \pm \\
18.8\end{array}$ & $\begin{array}{c}388.5 \pm \\
12.1\end{array}$ \\
\hline
\end{tabular}

Table (9) Mean Energy and selected macronutrients intake \pm SD per day among Girls 6-<12 years in EL Behaira governorates.

\begin{tabular}{|c|c|c|c|c|c|c|}
\hline \multirow{3}{*}{ Variables } & \multicolumn{3}{|c|}{ Urban } & \multicolumn{3}{|c|}{ Rural } \\
\hline & $\begin{array}{c}\text { Normal } \\
(34)\end{array}$ & $\begin{array}{c}\text { Obese } \\
(26)\end{array}$ & $\begin{array}{l}\text { Total } \\
(60)\end{array}$ & $\begin{array}{c}\text { Normal } \\
(27)\end{array}$ & Obese (22) & $\begin{array}{l}\text { Total } \\
(49)\end{array}$ \\
\hline & mean \pm SD & $\begin{array}{c}\text { mean } \pm \\
\text { SD }\end{array}$ & $\begin{array}{c}\text { mean } \pm \\
\text { SD }\end{array}$ & mean \pm SD & mean \pm SD & $\begin{array}{c}\text { mean } \pm \\
\text { SD }\end{array}$ \\
\hline Energy (Kcal) intake & $\begin{array}{c}2305 \pm \\
241.0 \\
\end{array}$ & $3092 \pm 323.3$ & $\begin{array}{l}2699 \pm \\
332.0 \\
\end{array}$ & $\begin{array}{c}2328 \pm \\
236.2 \\
\end{array}$ & $3072 \pm 119.8$ & $\begin{array}{l}2700 \pm \\
177.0 \\
\end{array}$ \\
\hline Mean RDA (Kcal) & 2250 & 2250 & 2250 & 2250 & 2250 & 2250 \\
\hline \% intake from RDA & $102.4 \%$ & $137.4 \%$ & $120.0 \%$ & $103.5 \%$ & $136.5 \%$ & $120.0 \%$ \\
\hline Total protein (g) intake & $\begin{array}{c}91.0 \pm \\
7.2\end{array}$ & $\begin{array}{c}108.2 \pm \\
8.7\end{array}$ & $\begin{array}{c}99.6 \pm \\
3.0\end{array}$ & $\begin{array}{c}85.6 \pm \\
3.5\end{array}$ & $\begin{array}{c}97.1 \pm \\
12.9\end{array}$ & $\begin{array}{l}91.4 \pm \\
12.1\end{array}$ \\
\hline RDA for protein /g & 36.5 & 36.5 & 36.5 & 36.5 & 36.5 & 36.5 \\
\hline \% intake from RDA & $249.3 \%$ & $296.4 \%$ & $273.0 \%$ & $234.5 \%$ & $266.0 \%$ & $250.4 \%$ \\
\hline Total fat (g) intake & $\begin{array}{c}72.1 \pm \\
14.0\end{array}$ & $\begin{array}{c}125.1 \pm \\
14.2\end{array}$ & $\begin{array}{c}98.6 \pm \\
14.0\end{array}$ & $\begin{array}{c}71.8 \pm \\
10.1\end{array}$ & $\begin{array}{c}93.7 \pm \\
10.5\end{array}$ & $\begin{array}{c}82.4 \pm \\
10.0\end{array}$ \\
\hline Cholesterol (mg) intake & $\begin{array}{c}169.4 \pm \\
16.9 \\
\end{array}$ & $\begin{array}{c}313.7 \pm \\
16.8 \\
\end{array}$ & $\begin{array}{c}241.6 \pm \\
16.0\end{array}$ & $177.6 \pm 12.5$ & $\begin{array}{c}229.0 \pm \\
17.9 \\
\end{array}$ & $\begin{array}{c}203.3 \pm \\
14.2 \\
\end{array}$ \\
\hline Carbohydrates (g) intake & $322.9 \pm 10.5$ & $\begin{array}{c}383.3 \pm \\
9.5\end{array}$ & $\begin{array}{c}\text { 353.1 } \pm \\
10.0\end{array}$ & $\begin{array}{c}335.0 \pm \\
12.1\end{array}$ & $\begin{array}{c}460.1 \pm \\
10.0\end{array}$ & $\begin{array}{c}397.5 \pm \\
16.6\end{array}$ \\
\hline
\end{tabular}


Table (10): Mean Minerals intake $\pm S D$ per day among Boys $6-<12$ years in the different study groups in EL Behirra governorates.

\begin{tabular}{|c|c|c|c|c|c|c|}
\hline \multirow{3}{*}{ Variables } & \multicolumn{3}{|c|}{ Urban } & \multicolumn{3}{|c|}{ Rural } \\
\hline & Normal(17) & Obese (24) & Total (41) & Normal(12) & Obese (26) & Total(38) \\
\hline & mean \pm SD & mean \pm SD & mean \pm SD & mean \pm SD & mean \pm SD & mean \pm SD \\
\hline Calcium(mg) intake & $1149.3 \pm 31.0$ & $1346.3 \pm 58.0$ & $1247.8 \pm 45.0$ & 833. \pm 25.1 & $874.4 \pm 32.8$ & $853.7 \pm 29.0$ \\
\hline Mean RDA/mg & 1000 & 1000 & 1000 & 1000 & 1000 & 1000 \\
\hline \%intake from RDA & $114.9 \%$ & $134.6 \%$ & $124.8 \%$ & $83.4 \%$ & $87.4 \%$ & $85.4 \%$ \\
\hline Iron $(\mathrm{mg})$ intake & $25.6 \pm 4.0$ & $30.3 \pm 3.1$ & $28.0 \pm 3.2$ & $26.2 \pm 1.8$ & $26.1 \pm 4.5$ & $26.1 \pm 1.6$ \\
\hline Mean RDA/mg & 11 & 11 & 11 & 11 & 11 & 11 \\
\hline \% intake from RDA & $232.7 \%$ & $275.5 \%$ & $254.5 \%$ & $238.2 \%$ & $237.3 \%$ & $237.3 \%$ \\
\hline Zinc (mg) intake & $11.1 \pm 2.8$ & $11.1 \pm 3.8$ & $11.1 \pm 3.3$ & $10.2 \pm 2.4$ & $11.8 \pm 3.4$ & $11.0 \pm 2.8$ \\
\hline Mean RDA/mg & 12.5 & 12.5 & 12.5 & 12.5 & 12.5 & 12.5 \\
\hline \%intake from RDA & $\mathbf{8 8 . 8 \%}$ & $\mathbf{8 8 . 8 \%}$ & $\mathbf{8 8 . 8 \%}$ & $81.6 \%$ & $94.4 \%$ & $\mathbf{8 8 . 0 \%}$ \\
\hline Copper $(\mu \mathrm{g})$ intake & $0.05 \pm 0.007$ & $0.04 \pm 0.005$ & $0.045 \pm 0.003$ & $0.05 \pm 0.001$ & $0.14 \pm 0.02$ & $0.1 \pm 0.01$ \\
\hline Mean RDA/ $\mu \mathrm{g}$ & 2 & 2 & 2 & 2 & 2 & 2 \\
\hline \%intake from RDA & $2.5 \%$ & $2.0 \%$ & $2.25 \%$ & $2.5 \%$ & $7.0 \%$ & $5.0 \%$ \\
\hline Selenium(mg)intake & $38.0 \pm 3.3$ & $37.2 \pm 4.9$ & $37.6 \pm 6 . .1$ & $35.6 \pm 4.9$ & $38.1 \pm 1.3$ & $36.9 \pm 3.6$ \\
\hline Mean RDA/mg & 35 & 35 & 35 & 35 & 35 & 35 \\
\hline \%intake from RDA & $108.5 \%$ & $106.3 \%$ & $107.4 \%$ & $101.7 \%$ & $108.9 \%$ & $113.1 \%$ \\
\hline
\end{tabular}

Table (11): Mean Minerals intake \pm SD per day among Girls 6-<12 years in the different study groups in EL Behaira governorates.

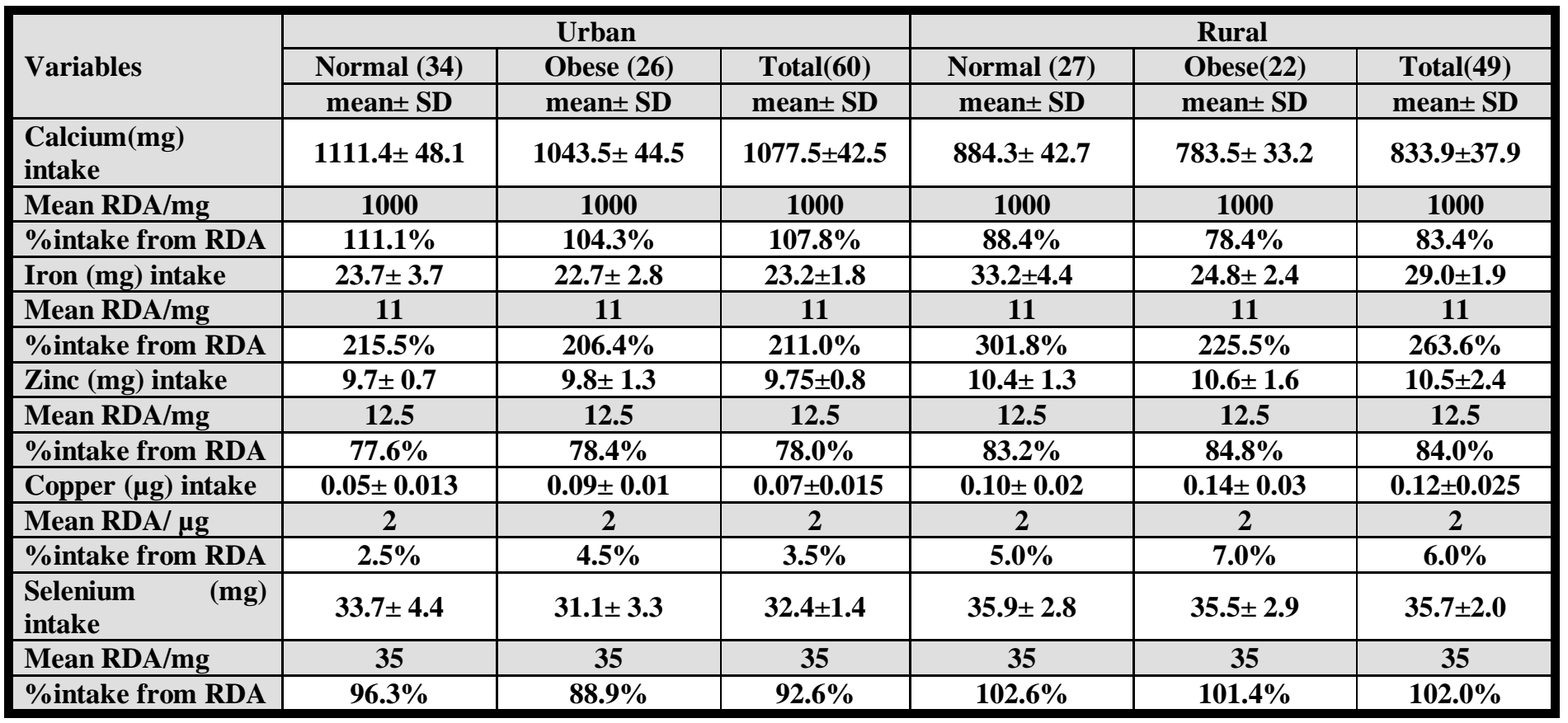


Table (12): Mean intake of Water soluble vitamins $\pm S D$ per day among Boys $6-<12$ years in the different study groups in EL Behirra governorates.

\begin{tabular}{|c|c|c|c|c|c|c|}
\hline \multirow{3}{*}{ Variables } & \multicolumn{3}{|c|}{ Urban } & \multicolumn{3}{|c|}{ Rural } \\
\hline & Normal (17) & Obese (24) & Total(41) & Normal (12) & Obese (26) & Total (38) \\
\hline & mean \pm SD & mean \pm SD & mean \pm SD & mean \pm SD & mean \pm SD & mean \pm SD \\
\hline Thiamin (mg) & $1.5 \pm 0.06$ & $1.5 \pm 0.07$ & $1.5 \pm 0.06$ & $1.3 \pm 0.04$ & $1.4 \pm 0.06$ & $1.35 \pm 0.05$ \\
\hline Mean RDA/ mg & 1.25 & 1.25 & 1.25 & 1.25 & 1.25 & 1.25 \\
\hline \% intake from RDA & $120.0 \%$ & $120.0 \%$ & $120.0 \%$ & $104.0 \%$ & $112.0 \%$ & $108.0 \%$ \\
\hline Riboflavin (mg) & $3.0 \pm 0.5$ & $3.3 \pm 0.2$ & $3.15 \pm 0.3$ & $2.1 \pm 0.1$ & $2.1 \pm 0.1$ & $2.1 \pm 0.1$ \\
\hline Mean RDA/ mg & $\mathbf{1 . 3 5}$ & $\mathbf{1 . 3 5}$ & 1.35 & 1.35 & 1.35 & 1.35 \\
\hline \%intake from RDA & $222.0 \%$ & $244.4 \%$ & $233.0 \%$ & $155.6 \%$ & $155.6 \%$ & $155.6 \%$ \\
\hline Niacin (mg) & $1.93 \pm 0.06$ & $2.15 \pm 0.09$ & $2.04 \pm \mathbf{0 . 0 7}$ & $1.67 \pm 0.05$ & $1.98 \pm 0.07$ & $1.79 \pm 0.06$ \\
\hline Mean RDA/ mg & 1.5 & 1.5 & 1.5 & 1.5 & 1.5 & 1.5 \\
\hline \% intake from RDA & $128.7 \%$ & $143.3 \%$ & $136.0 \%$ & $111.3 \%$ & $132.0 \%$ & $119.3 \%$ \\
\hline Folic acid $(\mu \mathrm{g})$ & $117.3 \pm 8.9$ & $97.6 \pm 4.5$ & $107.5 \pm 6 . .2$ & $95.5 \pm 6.4$ & $75.5 \pm 3.4$ & $85.5 \pm 4.0$ \\
\hline Mean RDA/ mg & 125 & 125 & 125 & 125 & 125 & 125 \\
\hline \%intake from RDA & $93.8 \%$ & $78.1 \%$ & $86.1 \%$ & $76.4 \%$ & $60.4 \%$ & $68.4 \%$ \\
\hline Vitamin C $(\boldsymbol{\mu g})$ & $135.2 \pm 7.8$ & $109.3 \pm 7.0$ & $122.2 \pm 7.0$ & $100.6 \pm 7.7$ & $145.6 \pm 8.4$ & $123.1 \pm 8.0$ \\
\hline Mean RDA/ mg & 47.5 & 47.5 & 47.5 & 47.5 & 47.5 & 47.5 \\
\hline \%intake from RDA & $284.6 \%$ & $230.1 \%$ & $257.3 \%$ & $211.8 \%$ & $306.5 \%$ & $259.2 \%$ \\
\hline
\end{tabular}

Table (13): Mean intake of Water soluble vitamins $\pm S D$ per day among Girls $6-<12$ years in the different study groups in EL Behaira governorates.

\begin{tabular}{|c|c|c|c|c|c|c|}
\hline \multirow{3}{*}{ Variables } & \multicolumn{3}{|c|}{ Urban } & \multicolumn{3}{|c|}{ Rural } \\
\hline & Normal (34) & Obese (26) & Total(60) & Normal (27) & Obese (22) & Total(49) \\
\hline & mean \pm SD & mean \pm SD & mean \pm SD & mean \pm SD & mean \pm SD & mean \pm SD \\
\hline Thiamin (mg) & $1.3 \pm 0.05$ & $1.3 \pm 0.05$ & $1.3 \pm 0.05$ & $1.5 \pm 0.04$ & $1.4 \pm 0.04$ & $1.45 \pm 0.05$ \\
\hline Mean RDA/ mg & 1.25 & 1.25 & 1.25 & 1.25 & 1.25 & 1.25 \\
\hline \% intake from RDA & $104.0 \%$ & $104.0 \%$ & $104.0 \%$ & $120.0 \%$ & $112.0 \%$ & $116.0 \%$ \\
\hline Riboflavin (mg) & $3.2 \pm 0.1$ & $3.2 \pm 0.6$ & $3.2 \pm 0.3$ & $2.3 \pm 0.2$ & $1.9 \pm 0.1$ & $2.1 \pm 0.4$ \\
\hline Mean RDA/ mg & 1.35 & 1.35 & 1.35 & 1.35 & 1.35 & 1.35 \\
\hline \% intake from RDA & $237.0 \%$ & $237.0 \%$ & $237.0 \%$ & $170.4 \%$ & $140.7 \%$ & $155.0 \%$ \\
\hline Niacin (mg) & $1.97 \pm 0.05$ & $1.91 \pm 0.07$ & $1.93 \pm 0.08$ & $1.82 \pm 0.06$ & $1.95 \pm 0.04$ & $1.9 \pm 0.05$ \\
\hline Mean RDA/ mg & 1.5 & 1.5 & 1.5 & 1.5 & 1.5 & 1.5 \\
\hline \% intake from RDA & $131.3 \%$ & $127.3 \%$ & $128.7 \%$ & $121.3 \%$ & $\mathbf{1 3 0 . 0 \%}$ & $126.7 \%$ \\
\hline Folic acid $(\boldsymbol{\mu g})$ & $86.1 \pm 7.7$ & $76.4 \pm 4.0$ & $81.3 \pm 4.1$ & $79.8 \pm 9.4$ & $61.8 \pm 3.2$ & $70.8 \pm 3.1$ \\
\hline Mean RDA/ mg & 125 & 125 & 125 & 125 & 125 & 125 \\
\hline \% intake from RDA & $68.9 \%$ & $61.1 \%$ & $65.0 \%$ & $63.8 \%$ & $49.4 \%$ & $56.6 \%$ \\
\hline Vitamin C $(\boldsymbol{\mu g})$ & $106.7 \pm 5.8$ & $128.2 \pm 9.5$ & $117.5 \pm 8.6$ & $114.6 \pm 7.5$ & $173.2 \pm 7.3$ & $143.9 \pm 8.4$ \\
\hline Mean RDA/ mg & 47.5 & 47.5 & 47.5 & 47.5 & 47.5 & 47.5 \\
\hline \% intake from RDA & $224.6 \%$ & $269.9 \%$ & $261.1 \%$ & $241.3 \%$ & $364.6 \%$ & $302.9 \%$ \\
\hline
\end{tabular}


Table (14) Mean intake of Fat soluble vitamins \pm SD per day among Boys $6-<12$ years was in the different study groups in EL Behirra governorates.

\begin{tabular}{|l|c|c|c|c|c|c|}
\hline \multirow{2}{*}{ Variables } & \multicolumn{4}{|c|}{ Urban } & \multicolumn{3}{c|}{ Rural } \\
\cline { 2 - 7 } & Normal(17) & Obese(24) & Total(41) & Normal(12) & Obese (26) & Total(38) \\
\cline { 2 - 7 } & mean \pm SD & mean \pm SD & mean \pm SD & mean \pm SD & Mean \pm SD & mean \pm SD \\
\hline $\begin{array}{l}\text { Vitamin A (Retinol equivalent } \\
\text { RE) }\end{array}$ & $\mathbf{9 5 6 . 3} \pm \mathbf{4 7 . 9}$ & $\mathbf{9 8 1 . 2 \pm 3 2 . 7}$ & $\mathbf{9 6 8 . 8} \pm 40.3$ & $\mathbf{6 3 6 . 2 \pm 3 8 . 6}$ & $\mathbf{7 7 3 . 9 \pm 3 5 . 3}$ & $\mathbf{7 0 5 . 0 \pm 3 7 . 0}$ \\
\hline $\begin{array}{l}\text { Mean RDA (Retinol equivalent } \\
\text { RE) }\end{array}$ & $\mathbf{8 5 0}$ & $\mathbf{8 5 0}$ & $\mathbf{8 5 0}$ & $\mathbf{8 5 0}$ & $\mathbf{8 5 0}$ & $\mathbf{8 5 0}$ \\
\hline \%intake from RDA & $\mathbf{1 1 2 . 5 \%}$ & $\mathbf{1 1 5 . 4 \%}$ & $\mathbf{1 1 4 \%}$ & $\mathbf{7 4 . 8 \%}$ & $\mathbf{9 1 . 0 \%}$ & $\mathbf{8 2 . 9 \%}$ \\
\hline Vitamin'E'/mg & $\mathbf{6 . 4 \pm 0 . 4}$ & $\mathbf{6 . 0} \pm \mathbf{0 . 9}$ & $\mathbf{6 . 2 \pm 0 . 2}$ & $\mathbf{6 . 6} \pm \mathbf{0 . 2}$ & $\mathbf{7 . 5} \pm \mathbf{0 . 7}$ & $\mathbf{7 . 1} \pm 0.9$ \\
\hline Mean RDA/mg & $\mathbf{8 . 5}$ & $\mathbf{8 . 5}$ & $\mathbf{8 . 5}$ & $\mathbf{8 . 5}$ & $\mathbf{8 . 5}$ & $\mathbf{8 . 5}$ \\
\hline \%intake from RDA & $\mathbf{7 5 . 3 \%}$ & $\mathbf{7 0 . 6 \%}$ & $\mathbf{7 2 . 9 \%}$ & $\mathbf{7 7 . 6 \%}$ & $\mathbf{8 8 . 2 \%}$ & $\mathbf{8 3 . 5 \%}$ \\
\hline
\end{tabular}

Table (15): Mean intake of Fat soluble vitamins $\pm S D$ per day among Girls 6-<12 years was in the different study groups in EL Behaira governorates.

\begin{tabular}{|c|c|c|c|c|c|c|}
\hline \multirow{3}{*}{ Variables } & \multicolumn{3}{|c|}{ Urban } & \multicolumn{3}{|c|}{ Rural } \\
\hline & Normal (34) & Obese (26) & Total(60) & Normal(27) & Obese (22) & Total(49) \\
\hline & mean \pm SD & mean \pm SD & mean \pm SD & mean \pm SD & Mean SD & mean \pm SD \\
\hline Vitamin A (Retinol equivalent RE) & $1058.2 \pm 52.4$ & $930.2 \pm 42.1$ & $994.2 \pm 47.3$ & $668.3 \pm 31.8$ & $763.9 \pm 37.1$ & $716.1 \pm 34.5$ \\
\hline $\begin{array}{l}\text { Mean RDA (Retinol equivalent } \\
\text { RE) }\end{array}$ & 850 & 850 & 850 & 850 & 850 & 850 \\
\hline \% intake from RDA & $124.5 \%$ & $109.4 \%$ & $117.0 \%$ & $78.6 \%$ & $89.9 \%$ & $84.2 \%$ \\
\hline Vitamin 'E'/mg & $5.5 \pm 0.4$ & $5.5 \pm 0.3$ & $5.5 \pm 0.8$ & $7.1 \pm 0.7$ & $7.5 \pm 0.7$ & $7.3 \pm 0.2$ \\
\hline Mean RDA/ mg & 8.5 & 8.5 & 8.5 & 8.5 & 8.5 & 8.5 \\
\hline \%intake from RDA & $64.7 \%$ & $64.7 \%$ & $64.7 \%$ & $83.5 \%$ & $88.2 \%$ & $85.9 \%$ \\
\hline
\end{tabular}

Table (16) Mean $\pm S D$ of Body Composition Fat Analyzer according sex, site and age group in EL-Behaira governorate.

\begin{tabular}{|c|c|c|c|c|c|c|c|c|c|c|}
\hline \multirow{3}{*}{ Age } & \multirow{3}{*}{ Variables } & \multicolumn{3}{|c|}{ Site } & \multicolumn{3}{|c|}{ Sex } & \multicolumn{3}{|c|}{ Weight status } \\
\hline & & Urban & Rural & \multirow[b]{2}{*}{$\mathrm{P}$} & Boys & "Girls & \multirow[b]{2}{*}{$\mathrm{P}$} & Normal & Obese & \multirow[b]{2}{*}{$\mathrm{P}$} \\
\hline & & $\begin{array}{c}\text { mean } \pm \\
\text { SD }\end{array}$ & $\begin{array}{c}\text { mean } \pm \\
\text { SD }\end{array}$ & & $\begin{array}{c}\text { mean } \pm \\
\text { SD }\end{array}$ & $\begin{array}{c}\text { mean } \pm \\
\text { SD }\end{array}$ & & $\begin{array}{c}\text { mean } \pm \\
\text { SD }\end{array}$ & $\begin{array}{c}\text { mean } \pm \\
\text { SD }\end{array}$ & \\
\hline \multirow{4}{*}{$6-12$} & $\begin{array}{l}\text { BMR } \\
\text { (Kcal) }\end{array}$ & $\begin{array}{l}1382.0 \pm \\
74.0\end{array}$ & $\begin{array}{l}1375.2 \pm \\
48.0\end{array}$ & 0.81 & $\begin{array}{l}1509.6 \pm \\
92.0\end{array}$ & $\begin{array}{l}1291.0 \pm \\
27.0\end{array}$ & $0.000 *$ & $\begin{array}{c}1262.8 \pm \\
54.0\end{array}$ & $\begin{array}{c}1502.3 \pm \\
20.0\end{array}$ & $0.000 *$ \\
\hline & FM (Kg) & $\begin{array}{l}15.8 \pm \\
1.12 \\
\end{array}$ & $\begin{array}{l}16.3 \pm \\
1.36\end{array}$ & 0.61 & $\begin{array}{l}16.4 \pm \\
1.52 \\
\end{array}$ & $\begin{array}{l}15.7 \pm \\
1.81 \\
\end{array}$ & 0.409 & $\begin{array}{c}11.6 \pm \\
0.37 \\
\end{array}$ & $\begin{array}{c}20.7 \pm \\
1.48 \\
\end{array}$ & $0.000^{*}$ \\
\hline & FFM (Kg) & $\begin{array}{l}31.1 \pm \\
5.41\end{array}$ & $\begin{array}{l}31.0 \pm \\
4.59\end{array}$ & 0.90 & $\begin{array}{l}31.9 \pm \\
5.16\end{array}$ & $\begin{array}{c}30.4 \pm \\
5.05\end{array}$ & $0.039 *$ & $\begin{array}{c}30.1 \pm \\
4.32\end{array}$ & $\begin{array}{c}31.8 \pm \\
5.82\end{array}$ & 0.095 \\
\hline & TBW (Kg) & $\begin{array}{c}22.8 \pm \\
3.96 \\
\end{array}$ & $\begin{array}{l}22.7 \pm \\
3.36 \\
\end{array}$ & $0.00 *$ & $\begin{array}{l}23.4 \pm \\
3.78 \\
\end{array}$ & $\begin{array}{l}22.3 \pm \\
3.70\end{array}$ & $0.038 *$ & $\begin{array}{c}22.0 \pm \\
3.2 \\
\end{array}$ & $\begin{array}{c}23.3 \pm \\
4.26 \\
\end{array}$ & 0.096 \\
\hline
\end{tabular}

*BMR: Basel Metabolic Rate *FM: Fat Mass *FFM: Fat Free Mass

*TBW: Total Body Water $\quad$ *Significantly Different at $\mathrm{P}<0.05$ 
Table (17) mean and SD values of laboratory parameters of children $6-<12$ years according to weight status in EL Behaira governorate

\begin{tabular}{|c|c|c|c|c|c|c|c|c|}
\hline \multirow{2}{*}{\multicolumn{2}{|c|}{$\begin{array}{l}\text { gender and } \\
\text { Parameters }\end{array}$}} & \multicolumn{3}{|c|}{ Urban } & \multicolumn{3}{|c|}{ Rural } & \multirow{3}{*}{$\begin{array}{l}* \mathbf{P} \\
0.0 \\
0 \\
\end{array}$} \\
\hline & & \multirow{2}{*}{$\begin{array}{c}\text { Normal } \\
84.5 \pm \\
6.1 \\
\end{array}$} & \multirow{2}{*}{$\begin{array}{c}\text { Obese } \\
93.5 \pm 7 . \\
8 \\
\end{array}$} & \multirow{2}{*}{$\begin{array}{c}\text { Total } \\
89.0 \pm 7.0 \\
*\end{array}$} & \multirow{2}{*}{$\begin{array}{c}\text { Normal } \\
93.4 \\
\pm 12.7 \\
\end{array}$} & \multirow{2}{*}{$\begin{array}{c}\text { Obese } \\
101.6 \pm 8 . \\
0 \\
\end{array}$} & \multirow{2}{*}{$\begin{array}{c}\text { Total } \\
97.5 \pm 5.4^{*}\end{array}$} & \\
\hline \multirow{8}{*}{$\begin{array}{c}\text { boy } \\
\text { s }\end{array}$} & $\begin{array}{l}\text { Glucose } \\
\mathrm{mg} / \mathrm{dl}\end{array}$ & & & & & & & \\
\hline & $\begin{array}{l}\text { Cholestero } \\
1 \mathrm{mg} / \mathrm{dl} \\
\end{array}$ & $\begin{array}{c}171.1 \pm \\
8.0 \\
\end{array}$ & $\begin{array}{c}194.9 \\
\pm 6.9 \\
\end{array}$ & $\begin{array}{c}183.0 \pm 12 \\
.5 \\
\end{array}$ & $\begin{array}{c}158.4 \pm 10 \\
.0 \\
\end{array}$ & $\begin{array}{c}195.8 \pm 6 . \\
6 \\
\end{array}$ & $177.1 \pm 3.3$ & NS \\
\hline & $\begin{array}{l}\text { H.D.L } \\
\text { mg/dl }\end{array}$ & $\begin{array}{c}54.5 \pm \\
1.2 \\
\end{array}$ & $\begin{array}{l}48.4 \\
\pm 0.2 \\
\end{array}$ & $\begin{array}{c}51.5 \pm 0.7 \\
* \\
\end{array}$ & $44.2 \pm 1.0$ & $41.8 \pm 0.6$ & $43.0 \pm 0.9 *$ & $\begin{array}{c}0.0 \\
0 \\
\end{array}$ \\
\hline & $\begin{array}{l}\text { L.D.L } \\
\mathrm{mg} / \mathrm{dl}\end{array}$ & $\begin{array}{c}89.4 \pm \\
1.4 \\
\end{array}$ & $\begin{array}{c}101.4 \pm 1 \\
.7 \\
\end{array}$ & $\begin{array}{c}95.4 \pm 1.3 \\
* \\
\end{array}$ & $74.0 \pm 2.7$ & $\begin{array}{c}103.1 \pm 2 . \\
3 \\
\end{array}$ & $88.6 \pm 2.4^{*}$ & NS \\
\hline & $\begin{array}{l}\text { Triglycerid } \\
\text { es mg/dl }\end{array}$ & $\begin{array}{c}104.1 \pm 2 \\
.5 \\
\end{array}$ & $\begin{array}{c}110.9 \\
\pm 3.8 \\
\end{array}$ & $\begin{array}{c}107.5 \pm 3 . \\
2 \\
\end{array}$ & $\begin{array}{c}111.1 \pm 4 . \\
8 \\
\end{array}$ & $\begin{array}{c}125.0 \pm 3 \\
5 \\
\end{array}$ & $\begin{array}{c}118.1 \pm 3.8 \\
* \\
\end{array}$ & $\begin{array}{c}0.0 \\
0 \\
\end{array}$ \\
\hline & $\begin{array}{l}\text { T.S.H } \\
\text { mg/dl } \\
\end{array}$ & $6.5 \pm 0.7$ & $\begin{array}{l}4.01 \\
\pm 1.1 \\
\end{array}$ & $5.3 \pm 0.9$ & $5.1 \pm 0.0$ & $4.42 \pm 1.7$ & $4.8 \pm 0.8 *$ & NS \\
\hline & $\begin{array}{l}\text { Chromium } \\
\mu \mathrm{g} / \mathrm{dl}\end{array}$ & $0.4 \pm 0.0$ & $\begin{array}{l}0.45 \\
\pm 0.0 \\
\end{array}$ & $\begin{array}{c}0.43 \pm 0.0 \\
* \\
\end{array}$ & $0.3 \pm 0.0$ & $\begin{array}{c}0.33 \pm 0.0 \\
1 \\
\end{array}$ & $0.32 \pm 0.05$ & NS \\
\hline & Zinc mg/dl & $\begin{array}{c}10.9 \pm \\
0.1 \\
\end{array}$ & $\begin{array}{c}12.2 \\
\pm 1.01 \\
\end{array}$ & $\begin{array}{c}11.6 \pm \\
1.6^{*} \\
\end{array}$ & $\begin{array}{c}12.95 \pm 1 \\
6 \\
\end{array}$ & $\begin{array}{c}11.65 \pm 2 . \\
9 \\
\end{array}$ & $12.3 \pm 2.3 *$ & NS \\
\hline \multirow{8}{*}{$\begin{array}{c}\text { Girl } \\
\mathbf{s}\end{array}$} & $\begin{array}{l}\text { Glucose } \\
\text { mg/dl }\end{array}$ & $\begin{array}{c}91.3 \pm \\
122 . \\
\end{array}$ & $\begin{array}{c}95.7 \\
\pm 14.7 \\
\end{array}$ & $\begin{array}{c}93.5 \pm 11 . \\
0\end{array}$ & $98.0 \pm 9.3$ & $\begin{array}{c}108.0 \pm 12 \\
.4 \\
\end{array}$ & $\begin{array}{c}103.0 \pm 13 . \\
9 *\end{array}$ & 0.0 \\
\hline & $\begin{array}{l}\text { Cholestero } \\
1 \mathrm{mg} / \mathrm{dl}\end{array}$ & $\begin{array}{c}160.2 \pm \\
23.4 \\
\end{array}$ & $\begin{array}{l}194.2 \\
\pm 28.5 \\
\end{array}$ & $\begin{array}{c}177.2 \pm 16 \\
.0 \\
\end{array}$ & $\begin{array}{c}156.2 \pm 12 \\
.6 \\
\end{array}$ & $\begin{array}{c}190.8 \pm 16 \\
.4 \\
\end{array}$ & $\begin{array}{c}173.5 \pm 14 . \\
5 \\
\end{array}$ & NS \\
\hline & $\begin{array}{l}\text { H.D.L } \\
\text { mg/dl }\end{array}$ & $\begin{array}{c}4885 . \pm \\
10.8 \\
\end{array}$ & $\begin{array}{c}43.0 \pm \\
10.3 \\
\end{array}$ & $\begin{array}{c}43.93 \pm 10 \\
.5 \\
\end{array}$ & $\begin{array}{c}45.6 \pm 10 . \\
3 \\
\end{array}$ & $\begin{array}{c}492 . \pm \\
13.7 \\
\end{array}$ & $46.4 \pm 11.7$ & NS \\
\hline & $\begin{array}{l}\text { L.D.L } \\
\mathrm{mg} / \mathrm{dl}\end{array}$ & $\begin{array}{r}97.2 \\
\pm 23.4 \\
\end{array}$ & $\begin{array}{l}102.1 \\
\pm 14.4 \\
\end{array}$ & $\begin{array}{c}99.7 \pm 18 . \\
9 \\
\end{array}$ & $\begin{array}{c}97.5 \pm 49 . \\
4 \\
\end{array}$ & $\begin{array}{c}125.6 \pm 13 \\
.8 \\
\end{array}$ & $\begin{array}{c}111.6 \pm 16 . \\
6^{*}\end{array}$ & 0.0 \\
\hline & $\begin{array}{l}\text { Triglycerid } \\
\text { e mg/dl }\end{array}$ & $\begin{array}{r}104.8 \\
\pm 10.6 \\
\end{array}$ & $\begin{array}{l}110.7 \\
\pm 28.0 \\
\end{array}$ & $\begin{array}{c}107.8 \pm 14 \\
.3 \\
\end{array}$ & $\begin{array}{c}103.2 \pm 17 \\
.5 \\
\end{array}$ & $\begin{array}{c}116.3 \pm 41 \\
.7 \\
\end{array}$ & $\begin{array}{c}109.8 \pm 39 . \\
2 * \\
\end{array}$ & NS \\
\hline & $\begin{array}{l}\text { T.S.H } \\
\text { mg/dl }\end{array}$ & $3.1 \pm 1.3$ & $\begin{array}{c}1.66 \pm \\
0.0 \\
\end{array}$ & $2.4 \pm 1.3$ & $2.33 \pm 1.1$ & $1.1 \pm 0.0$ & $1.7 \pm 1.0 *$ & 0.0 \\
\hline & $\begin{array}{l}\text { Chromium } \\
\mu \mathrm{g} / \mathrm{dl}\end{array}$ & $0.3 \pm 0.1$ & $\begin{array}{c}0.4 \\
\pm 0.14 \\
\end{array}$ & $\begin{array}{l}0.35 \pm 0.1 \\
2^{*} \\
\end{array}$ & $0.33 \pm 0.1$ & $0.3 \pm 0.0$ & $0.32 \pm .01$ & 0.0 \\
\hline & Zinc mg/dl & $\begin{array}{c}10.6 \pm \\
1.5 \\
\end{array}$ & $\begin{array}{c}16.4 \pm \\
2.5\end{array}$ & $\begin{array}{c}13.5 \pm \\
2.0 * \\
\end{array}$ & $12.1 \pm 1.8$ & $\begin{array}{c}15.53 \pm 2 . \\
4 \\
\end{array}$ & $13.8 \pm 2.1 *$ & NS \\
\hline
\end{tabular}

- *Significantly Different at $\mathrm{P}<0.05$ between sex

$* \mathbf{P}$ Significantly Different at $\mathrm{P}<0.05$ between sites. 


\section{الملخص العربي}

\section{التقيِم التغذوي لأطفالِ المدارس الإبتدائيةِ البدناء في المناطق الحضريِِِ والريفية

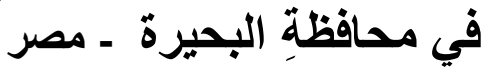

$$
\text { هناء حسين السيد - سحر خيري ـ محمد كمال عبد الرحمن- عفت عبده عفيفي القئية }
$$

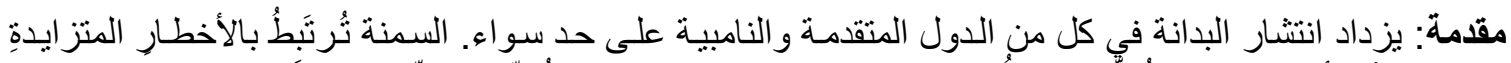

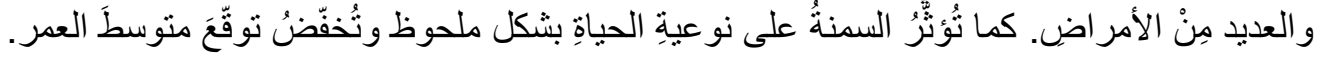

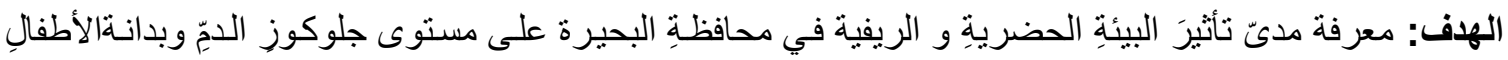

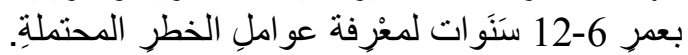

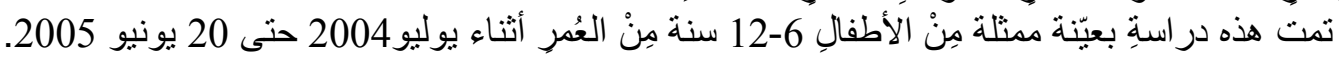

الطرق:تم تحديد المقاييس الجسمية للاطفال وكذللك معرفة كمية المتناول من الغذاء ومحتوى هذا الغذاء من العناصر

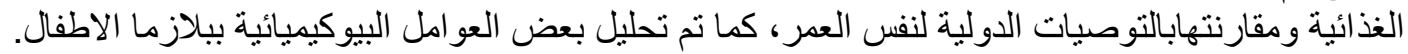

$$
\text { النتائج: اظهرت النتائج ما يلي: }
$$

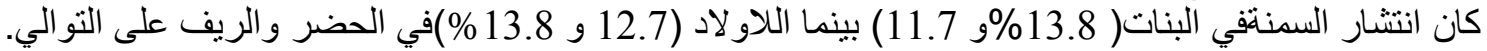

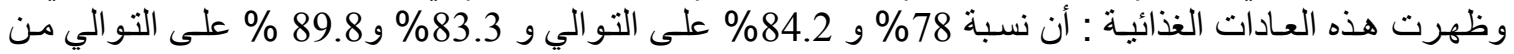

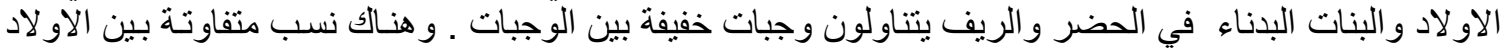

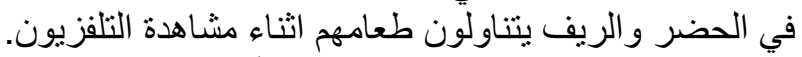

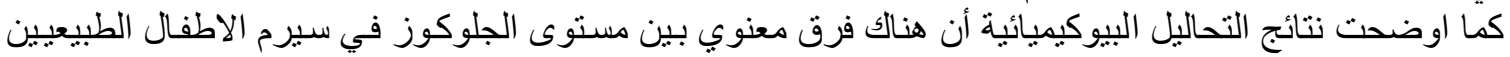

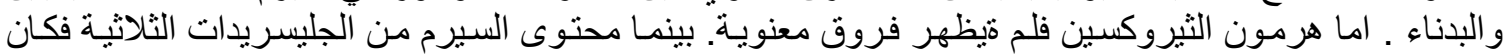

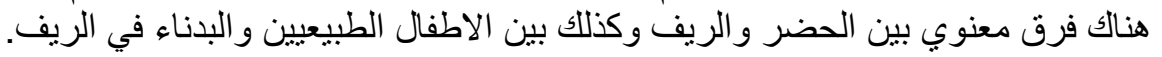

